Notre Dame Law Review

Volume 83 | Issue 1

Article 4

$11-1-2007$

\title{
The Jurisprudence of Colliding First Amendment Interests: From the Dead End of Neutrality to the Open Road of Participation-Enhancing Review
}

Gregory P. Magarian

Follow this and additional works at: http://scholarship.law.nd.edu/ndlr

\section{Recommended Citation}

Gregory P. Magarian, The Jurisprudence of Colliding First Amendment Interests: From the Dead End of Neutrality to the Open Road of Participation-Enhancing Review, 83 Notre Dame L. Rev. 185 (2007).

Available at: http://scholarship.law.nd.edu/ndlr/vol83/iss1/4 


\title{
THE JURISPRUDENCE OF COLLIDING FIRST
}

\author{
AMENDMENT INTERESTS: FROM THE DEAD END \\ OF NEUTRALITY TO THE OPEN ROAD OF \\ PARTICIPATION-ENHANCING REVIEW
}

\author{
Gregory P. Magarian*
}

First Amendment interests in both speech and religion often collide with one another. A political activist claims a free speech interest in the right to purchase advertising time on a television network, while the network claims a free speech interest in its decision not to sell the time. A religious enclave claims a free exercise interest in having a dedicated public school district, while its neighbors claim a nonestablishment interest in the government's not extending the group special treatment. In this Article Professor Magarian examines the phenomenon of colliding First Amendment interests, explains and critiques the Supreme Court's failure to acknowledge and resolve First Amendment collisions, and proposes a new theoretical basis for resolving them: participationenhancing review. The Article first catalogues Supreme Court cases that involve colliding First Amendment interests, including expressive access, religious accommodation, and religious speech disputes. The Court avoids confronting First Amendment collisions through two techniques: denial that one or the other interest exists or matters, and deference to elected officials' balancing of the competing interests. The Court's approach embodies a strong posture of judicial neutrality, based on the concern that substantive resolution of First Amendment collisions would interfere with elected officials' policymaking discretion. Professor Magarian contends that the Court disserves democracy when it abrogates its duty to construe and enforce the critical protections of the First Amendment. He proposes substantive resolution of First Amendment collisions

(c) 2007 Gregory P. Magarian. Individuals and nonprofit institutions may reproduce and distribute copies of this Article in any format, at or below cost, for educational purposes, so long as each copy identifies the author, provides a citation to the Notre Dame Law Review, and includes this provision and copyright notice.

* Professor of Law, Villanova University. Thanks to Mike Carroll, Ellen Goodman, Michael Moreland, Christina Wells, and workshop participants at the University of Missouri-Columbia School of Law for helpful comments on an earlier draft. 
under the theory of participation-enhancing review, a variation on the familiar theory of representation-reinforcing review. Representation reinforcement theory roots judicial enforcement of constitutional rights in democratic principles. Representation reinforcement, however, cannot justify substantive resolution of First Amendment collisions, because the theory rests on a formal account of democratic participation that does not encompass First Amendment collisions. Participation-enhancing review, in contrast, rests on a substantive account of democratic participation, which would commit First Amendment doctrine to protecting the inclusive and informational attributes of democratic discourse. Such an approach would lead courts, in analyzing First Amendment collisions, to emphasize the distinctive value for democracy of expressive dissension and religious pluralism.

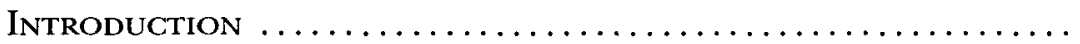

I. The Supreme Court's Failure to Resolve Collisions of First Amendment Interests $\ldots \ldots \ldots \ldots \ldots \ldots \ldots \ldots \ldots, 190$

A. Conflicting Free Speech Claims: Access vs. Autonomy ....... 191

1. Claims for Access to Expressive Property........ 193

2. Media Access Cases .................... 199

3. Copyright Disputes ................... 203

4. Campaign Finance Challenges............ 206

5. The Press vs. Privacy: Bartnicki v. Vopper......... 208

B. The Free Exercise Clause vs. the Establishment Clause:

Religious Accommodation Decisions .............. 210

1. Mandatory Accommodation Cases ........... 212

a. Mandatory Accommodations Granted....... 212

b. Mandatory Accommodations Denied....... 215

2. Permissive Accommodation Cases ........... 218

a. Permissive Accommodations Upheld ........ 218

b. Permissive Accommodations Struck Down .... 221

3. Employment Division v. Smith and Judicial Abstention from Constitutional Questions of Religious

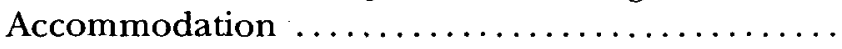

a. The Smith Decision................. 223

b. Permissive Accommodation After Smith .......

c. The Free Speech Clause vs. the Establishment Clause: Religious Speakers' Claims on Public Resources ..........................

II. Resolving First Amendment Collisions Under

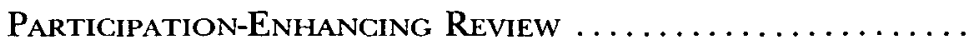

A. Neutrality as the Supreme Court's Conceptual Basis for Refusing to Confront First Amendment Conflicts..........

1. Neutrality in Expressive Access Cases ........... 
2. Neutrality in Religious Accommodation Cases .... 239

3. Neutrality in Religious Speech Cases........... 244

4. The Troubling Allure of Neutrality ........... 246

B. Participation-Enhancing Review as a Constitutional Basis for Resolving First Amendment Collisions ............. 249

1. The Value and Limits of RepresentationReinforcing Review.................... 249

2. The Substantive Participation Value and Participation-Enhancing Review of First Amendment Collisions .................... 254

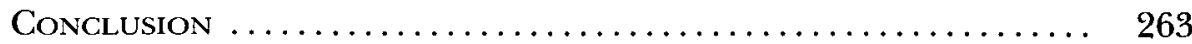

\section{INTRODUCTION}

The First Amendment imbues the Constitution with substantive democratic values. The Free Speech Clause, along with the guarantees of press freedom and the right to petition for redress of grievances, posit open communication as central to our social and political order. The Religion Clauses, with their intertwined commitments to free exercise and nonestablishment, make clear that religious toleration and governmental restraint in matters of conscience play a central role in the functioning of our constitutional system. Beyond such general descriptions, determining the precise content of First Amendment values requires continual evaluation and elaboration. Judges and their critics often preoccupy themselves with the fear that judicial articulation and application of constitutional values might overwhelm the authority of democratically elected officials. John Hart Ely, critiquing and defending judicial review in Democracy and Distrust, sought to address that fear by conceptualizing judicial enforcement of constitutional rights as a procedural aid to a substantive vision of democracy. ${ }^{1}$ Despite the influence of the theory Ely championed, First Amendment doctrine still reflects ingrained doubt that our democratic system can bear a robust regime of judicially enforced rights.

In both the expressive and religious contexts, legal disputes frequently arise that pit competing First Amendment interests against one another. A political dissenter claims a First Amendment right of access to buy advertising time from a broadcaster, but the broadcaster responds by claiming a First Amendment right of autonomy to reject the dissenter's ad. A religious group claims a free exercise right to exemption from a generally applicable law, obedience of which would seriously compromise the group's religious practices, but the govern-

1 See John Hart Ely, Democracy and Distrust 101-04 (1980). 
ment-or some objector with different religious commitments or none at all-responds that granting the exemption would violate the Establishment Clause. Sometimes expressive and religious currents cross, as when a religious speaker claims a free speech right to use government property or funding, but the government invokes the Establishment Clause to withhold the resource. Collisions of First Amendment interests present courts with harder challenges than cases in which the government blatantly censors speech, or suppresses or advances a particular faith. At the same time, First Amendment collisions present especially pressing and important conflicts between interests central to individual conscience and participatory democracy.

Unfortunately, when the Supreme Court confronts colliding First Amendment interests-whether in the context of speech, religion, or both-it consistently avoids any substantive analysis of the collision. Most commonly, the Court refuses even to acknowledge conflicting claims of constitutional magnitude, instead denying salience to one of the competing First Amendment interests. When dissident speakers seek access to expressive property, the Court routinely invokes a rigidly formalist version of the public-private distinction, or reduces speech protection to a simple matter of protecting the autonomy of powerful speakers, in order to reject any First Amendment right of access to means of expression. When religious believers seek exemptions from burdensome laws, the Court has variously ignored the free exercise interest or the nonestablishment interest. Alternatively, when legislation empowers an expressive or religious interest the Court might otherwise ignore, the Court routinely defers to legislative authority, thereby averting the need to make substantive judgments about the underlying constitutional interests. In the Court's most striking display of deference, it now treats both the Free Exercise Clause and the Establishment Clause as virtually irrelevant to legislative exemptions for religious believers from the ordinary effects of legal rules. Both of these approaches to First Amendment collisions reflect an unwavering commitment to an ideal of judicial neutrality. That commitment embodies the Justices' view that democratic principles compel restraint when First Amendment interests collide.

The Court's insistence on maintaining neutrality in matters of colliding expressive and religious interests has deterred it from substantively resolving First Amendment collisions. This Article proposes an alternative, constitutionally grounded decisional value that would equip the Court to resolve collisions between expressive and/or religious claims: the advancement of participation in democratic self-government. Building upon Ely's theory of representation-reinforcing 
judicial review, which similarly attempts to base judicial assertiveness on democratic principles, I label the proposed theory participationenhancing review. Where representation-reinforcing review validates judicial repairs to the democratic process based on a formal value of political participation, participation-enhancing review would validate substantive judicial resolution of First Amendment collisions under a substantive value of participation. The substantive participation value embodies society's collective interest in public discourse that is both informative and inclusive, and it highlights the particular importance of dissent and difference for a healthy democratic system. In collisions of expressive interests, participation-enhancing review would lead the Court to favor outcomes that tended to expand the range of ideas present and audible in public debate. In collisions of religious interests, the Court would favor outcomes that maximized the capacities of different religious believers-and nonbelievers - to participate in democratic discourse on a full and equal basis. Participationenhancing review would not generate politically determined results, but it would ground resolution of First Amendment collisions in a broadly shared substantive value of democratic participation.

The Article proceeds in two parts, the first descriptive and the second prescriptive. Part I catalogues the broad and varied range of collisions between First Amendment interests and explains how the Supreme Court deals with them. Through separately assessing expressive access cases, religious accommodation cases, and cases that pit expressive autonomy against nonestablishment interests, Part I generates novel insights about First Amendment doctrine. The Justices avoid substantive resolution of First Amendment collisions through two complementary techniques: denial, whereby the Court conceptualizes First Amendment collisions as presenting only one sort of constitutional interest; and deference, whereby the Court yields to legislative or regulatory resolutions of First Amendment collisions. Those two techniques, their proportions adjusted to suit the terrain on which each sort of collision occurs, characterize all three of these seemingly disparate lines of First Amendment decisions. The case discussion in Part $I$ is dense and detailed because it comprehensively documents the important phenomenon of First Amendment collisions within and across the various fields of First Amendment doctrine.

Part II criticizes the Court's avoidance of First Amendment collisions and proposes the alternative of participation-enhancing review. The first section offers an explanation for the judicial approach to First Amendment collisions documented in Part I. It distills the idea of neutrality as the conceptual fuel that drives the Court's practices of denial and deference, and it explains why the Court's commitment to 
neutrality leads to inadequate decisions and normatively biased outcomes. The second section proposes the advancement of democratic participation as a substantive, democratically legitimate basis for resolution of First Amendment collisions. It first explains how the theory of representation-reinforcing review, which rests on a formal account of democratic participation, provides a promising but ultimately insufficient template for adjudicating collisions of First Amendment interests. It then introduces the substantive participation value, which embodies the informative and inclusive dimensions of democratic participation, as the basis for participation-enhancing review. It describes the analytic inquiries participation-enhancing review would require and addresses some likely criticisms. Participation-enhancing review would provide a democratically grounded framework for ensuring that the First Amendment, authoritatively construed by courts, governs collisions of First Amendment interests.

\section{The Supreme Court's Failure to Resolve Collisions of First AMENDMENT INTEREsts}

The Supreme Court, in the contexts of both expressive and religious freedom, has confronted important lines of cases in which parties on both sides could, and often do, coherently assert interests protected by the First Amendment. This Part identifies those lines of cases, analyzes the Court's dispositions of them, and reveals the remarkably similar modes of analysis the Court brings to bear on all varieties of collisions between First Amendment interests. Although the discussion encompasses a great many cases, I focus my analysis on the First Amendment collision each case presents, in order to provide a comprehensive catalogue of those collisions and to analyze the distinctive sort of difficulty in which they envelop the Court. This exhaustive exercise is necessary both to substantiate the descriptive connections I draw among the various lines of First Amendment collision cases and to enable the diagnostic, critical, and prescriptive contentions I advance in Part II.

The first section describes the several varieties of expressive access cases-property, mass media, campaign finance, and copyright disputes-which set interests in access to expressive property against expressive property owners' expressive autonomy interests. The second section describes the various permutations of religious accommodation cases, which set free exercise interests against nonestablishment interests. The third section discusses a discrete line of religious speech cases, which set expressive interests against the Establishment Clause. Although speech and religion doctrines present distinct problems, a 
common pattern emerges from these three distinct lines of cases about First Amendment collisions. In all three settings, the Court shows great reluctance to recognize the presence of colliding First Amendment interests. The Court routinely denies the existence, or the salience for a given dispute, of one competing interest. In certain cases, where a discretionary government regulation rather than a constitutional claim advances one of the competing interests, the Court defers to the regulators, narrowing the scope of the other constitutional interest enough to allow the regulation to stand. The Court in expressive access cases most commonly engages in denial, while the explicit textual provenance of the competing interests in religious accommodation cases has led the Court to systematize deference, effectively deconstitutionalizing the question of religious accommodation. A persistent motif in all of these decisions is neutrality, which Part II will identify as the Court's methodological focus and attribute to the Justices' subordination of substantive First Amendment analysis to judicial restraint.

\section{A. Conflicting Free Speech Claims: Access vs. Autonomy}

The paradigmatic free speech case involves censorship. A private individual speaks; the government, threatened by or disapproving of the speech, attempts to silence and/or punish the speaker; a court, we hope, prevents the censorship unless the weightiest interest justifies it. In the late 1960s, however, the Supreme Court began to consider a different sort of First Amendment problem, one that highlighted the increasing importance of expressive property-such as media outlets, shopping centers, and political money-for effective participation in public debate. These expressive access cases typically pit a would-be speaker's interest in access to an important channel of communication against the channel owner's expressive autonomy interest in excluding the speaker. They present access claims similar to those that arise in public forum disputes, ${ }^{2}$ but expressive access cases involve expressive resources controlled by nominally private entities rather than the government and thus implicate the resource owners' expressive autonomy.

2 Cf., e.g., Cornelius v. NAACP Legal Def. \& Educ. Fund, Inc., 473 U.S. 788, 809-10 (1985) (rejecting political groups' claims for access to a federal government fundraising drive based in part on the government's interest in choosing its preferred beneficiaries). In public forum cases, the government's incapacity to claim constitutional rights, including expressive rights, submerges any conflict between expressive interests. 
Beginning in the late 1960 s, a succession of scholars set out arguments for finding in the First Amendment some right of access to means of expression. ${ }^{3}$ Their arguments garnered early, tentative support on the Court. ${ }^{4}$ More recently, two distinct critiques of access rights have come to dominate academic debate. Libertarians of both conservative and progressive stripes attack the idea of access rights as contrary to what they view as a constitutionally compelled distribution of expressive opportunities by economic markets. ${ }^{5}$ A second group of critics endorses the goal of broadening access to the means of expression through regulatory reform but rejects judicial invocation of the First Amendment to enhance access. ${ }^{6}$ Advocacy of access rights, like any theory of expressive freedom, necessarily entails a particular normative account of the First Amendment's purpose and scope. What access rights proponents and their critics share is an understanding that access and autonomy are distinct, internally coherent, normatively rooted free speech values whose tension requires substantive resolution.

In contrast, the Court has avoided addressing the tension. The Justices confront collisions between expressive access and autonomy interests in several distinct contexts-expressive property, the mass media, copyright, and money in politics-but each line of decisions generates the same narrative. The Court most commonly denies putative speakers' claims of access rights by presuming, with little or no

3 Important conceptualizations and defenses of expressive access rights include Jerome A. Barron, Freedom of the Press for Whom? 73-74 (1973); Owen M. Fiss, Liberalism Divided 154-58 (1996); Cass R. Sunstein, Democracy and the Problem of Free SPEech (1993); J.M. Balkin, Some Realism About Pluralism: Legal Realist Approaches to the First Amendment, 1990 DUke L.J. 375, 394-404; see also AlEXANDER Meiklejohn, Political Freedom 24-28 (1960) (positing that "[w] hat is essential is that ... everything worth saying shall be said" and that "[ $t]$ o that end . . it may be assumed that each of the known authenticated points of view shall have . . an assigned share of the time available").

4 See Red Lion Broad. Co. v. FCC, 395 U.S. 367, 400-01 (1969) (upholding a statutory provision for media access based on the public's interest in receiving information); Amalgamated Food Employees Union Local 590 v. Logan Valley Plaza, Inc., 391 U.S. 308, 315-20 (1968) (finding constitutional right of access for expressive purposes to privately owned shopping center), abrogated by Hudgens v. NLRB, 424 U.S. 507 (1976); see also discussion infra notes 8-13, 49-56 and accompanying text (further discussing Logan Valley and Red Lion).

5 See Gregory P. Magarian, Market Triumphalism, Electoral Pathologies, and the Abiding Wisdom of First Amendment Access Rights, 35 Hofstra L. Rev. 1373, 1388-1405 (2007) (describing and critically analyzing the libertarian critique of expressive access rights).

6 See id. at 1406-29 (describing and critically analyzing the regulatory reform critique of access rights). 
explanation, that the First Amendment protects only expressive autonomy, not expressive access. These cases employ a rigid version of the public-private distinction and an uncompromising notion of autonomy to reject access interests out of hand. In seeming contrast, where legislators or regulators enact access reforms, the Court narrowly defines aggrieved property owners' expressive autonomy interests by reference to specific qualities of the expressive property at issue, thereby allowing the access reforms to stand as a matter of government discretion. This move allows the Court to avoid any substantive explanation of how and to what extent expressive access interests, given legal force, challenge or complicate the primacy of expressive autonomy interests. ${ }^{7}$

\section{Claims for Access to Expressive Property}

The quintessential line of expressive access disputes involves claims for access to private property that has distinctive utility for expression. The earliest of these cases produced the Court's only explicit holding that the First Amendment compels access to a privately owned channel of expression. In Amalgamated Food Employees Union Local 590 v. Logan Valley Plaza, Inc., ${ }^{8}$ the Court held that the First Amendment required a private shopping center to permit labor pickets, notwithstanding the owners' property right to exclude trespassers. ${ }^{9}$ Writing for the majority, Justice Marshall placed the workers' First Amendment right to picket in the foreground of the case and treated their interest in access to the shopping center as a natural corollary to that right; in contrast, the decision treats the shopping center owners' common law right to exclude the picketers as categorically subordinate to the First Amendment right. ${ }^{10}$ The opinion, however, relies heavily on direct connections between state power and the ostensibly private autonomy rights at issue. Justice Marshall-invok-

7 Commentators on occasion have suggested that all free speech decisions implicate something like the expressive access problem. See Frederick Schauer, Uncoupling Free Speech, 92 Colum. L. REv. 1321, 1322-34 (1992) (characterizing free speech cases in general as shifting costs from speakers to the public); R. George Wright, Why Free Speech Cases Are as Hard (and as Easy) as They Are, 68 TENN. L. REv. 335, 336-41 (2001) (arguing that most challenged speech regulations can be explained by reference to "free speech values"). Only expressive access cases, however, involve direct collisions of free speech interests, and my analysis will demonstrate that the Court has treated these cases as distinctively impervious to substantive First Amendment analysis.

8391 U.S. 308 (1968), abrogated by Hudgens v. NLRB, 424 U.S. 507 (1976).

9 Id. at 324-25.

10 See id. at 313-15, 319-20. 
ing Marsh v. Alabama, ${ }^{11}$ in which the Court had rejected the efforts of a "company town" to restrict expressive activity ${ }^{12}$-emphasized the heavily regulated character of the shopping center and its functional identity with the traditional public square. ${ }^{13}$ Although Logan Valley boldly proclaimed the place of access rights in the First Amendment, the Court's reasoning suffered from two glaring weaknesses. First, reliance on the narrowly focused Marsh "public function" test left Logan Valley vulnerable to a more nuanced state action analysis. Second, the Court's easy dismissal of the shopping center owners' common law property interest created an opening for future expressive property owners to cast their exclusionary claims in the stronger steel of expressive autonomy.

The first of those weaknesses ensured the Logan Valley holding a short shelf life. In Lloyd Corp. $v$. Tanner, ${ }^{14}$ the Court rejected a First Amendment claim brought by antiwar activists who sought to distribute handbills in a shopping mall adjacent to public streets. ${ }^{15}$ Pivoting off the Logan Valley Court's prominent invocation of Marsh, Justice Powell's majority opinion technically limited Logan Valley to the specific context of picketing related to a property owner's business in an isolated suburban area. ${ }^{16}$ In the decision's key doctrinal move, however, Justice Powell denied that the activists had any First Amendment access right to counter the mall owners' property right to exclude them. ${ }^{17}$ Subsequently, in Hudgens $v . N L R B,{ }^{18}$ the Court acknowledged the primacy of the Lloyd Corp. Court's constitutional analysis over its factual analysis and accordingly abrogated Logan Valley. ${ }^{19}$ In doing so, the Court manifested its wholesale rejection of a First Amendment right of access to communicative channels: "[T] he constitutional guarantee of free expression has no part to play in a case such as this."20 In rejecting Logan Valley, the Court emphatically affirmed the constitutional status of the shopping center owners'

\footnotetext{
11326 U.S. 501 (1946).

12 See id. at 505-10.

13 See Logan Valley, 391 U.S. at 317-18 (emphasizing the functional similarities between a shopping center and the Marsh company town).

14407 U.S. 551 (1972).

15 Id. at $558,569-70$.

16 See id. at 561-67 (detailing the factual distinctions between Logan Valley and Marsh, on one hand, and Lloyd Corp., on the other).

17 See id. at 568 ("[T] his Court has never held that a trespasser or an uninvited guest may exercise general rights of free speech on property privately owned and used nondiscriminatorily for private purposes only.").

18424 U.S. 507 (1976).

19 See id. at $518-19$.

$20 I d$, at 521.
} 
autonomy interests-although not, at this stage, identifying those interests with the First Amendment-while categorically denigrating the putative speakers' access interests.

Subsequently, however, the Court rejected a First Amendment challenge to a discretionary regulation that gave speakers access to expressive property. In PruneYard Shopping Center $v$. Robins, ${ }^{21}$ the Court upheld the application of a provision of the California Constitution to allow a political group to solicit petition signatures in a privately owned shopping center ${ }^{22}$-exactly the sort of access to which the Court had found no First Amendment right in Hudgens. ${ }^{23}$ Exploiting the second weakness of Logan Valley, the PruneYard challenge notably framed the shopping center owners' interest in terms not only of property rights but also of the First Amendment right against compelled expression. ${ }^{24}$ As to the owners' property claim, Justice Rehnquist's majority opinion found that the California access provision fell short of a taking and therefore raised no concern under the Fifth and Fourteenth Amendments. ${ }^{25}$ The expressive autonomy claim presented a potentially thornier problem. The Court in Lloyd Corp. and Hudgens had denied the salience of expressive access as a constitutional matter, ${ }^{26}$ but the California provision put expressive access back in play. Had the PruneYard Court hewed to the prior decisions' singular emphasis on expressive autonomy, it would have needed to confront the tension between access and autonomy interests. Justice Rehnquist avoided that confrontation by holding that the shopping center's openness to the public and the lack of state direction behind the speakers' message minimized the owners' expressive autonomy interest. $^{27}$ The facts of this dispute therefore implicated no interest of constitutional magnitude, and the Court could defer to the authority of the state law. ${ }^{28}$ The opinion failed to explain how those conditions were any less present in the prior shopping mall speech cases.

The Court has continued to deny any First Amendment interest in access to expressive property, and it has fortified property owners'

\footnotetext{
21447 U.S. 74 (1980).

22 See id. at 77-79.

23 See supra notes 18-20 and accompanying text.

24 PruneYard, 447 U.S. at $85-87$ \& n.9.

25 See id. at 82-85.

26 See supra notes 17,20 and accompanying text.

27 PruneYard, 447 U.S. at 87.

28 Labeling PruneYard as a case of judicial deference to elected officials is technically inaccurate, as the "regulation" in PruneYard was a state constitutional provision as authoritatively interpreted by the state supreme court. See id. at 78. No less than a statute or regulation, however, the object of the Court's deference was a majoritarian source of legal authority.
} 
expressive autonomy interests. In Pacific Gas $\mathcal{E}$ Electric Co. v. Public Utilities Commission, ${ }^{29}$ the Court struck down a state regulatory requirement that a public utility provide space in its monthly billing envelopes to consumer advocates who opposed some of the utility's policies. ${ }^{30}$ Justice Powell's plurality opinion began by emphasizing the public information value of the First Amendment, the central theoretical element in expressive access claims, but he quickly repositioned that value to serve the utility's expressive autonomy interest. ${ }^{31}$ The plurality treated the case as an instance of the government's use of an access mandate to undermine a property owner's expressive autonomy. ${ }^{32}$ The plurality distinguished PruneYard by asserting that the utility had a substantially greater expressive autonomy interest at stake than the shopping center owner, ${ }^{33}$ a position Justice Marshall echoed in his opinion concurring in the judgment. ${ }^{34}$ The facts of the two cases arguably belie the distinction, but it demonstrates the Court's increasing equation of property with speech. The plurality denied any possibility of a First Amendment access interest for the consumer advocates by equating access reforms with impermissible contentbased restrictions on property owners' expressive autonomy. ${ }^{35}$ Thus, Justice Powell managed to condemn an effort to balance public debate as "one-sidedness." 36

Most recently, in Hurley $v$. Irish-American Gay, Lesbian $\mathcal{E}^{2}$ Bisexual Group of Boston, Inc., ${ }^{37}$ the Court unanimously sustained a First Amendment challenge to a gay group's invocation of a state antidiscrimination law to compel the group's inclusion in a St. Patrick's Day parade. ${ }^{38}$ Hurley represents the apotheosis of the public-private distinction as a mechanism for elevating property owners' expressive autonomy and denigrating dissident speakers' interest in access to expressive property. The parade organizers relied for their expressive opportunity on a parade permit that the state granted them as a matter of tradition and routine, as well as other state support and funding. ${ }^{39}$ Beyond banning the gay group, the organizers' expressive

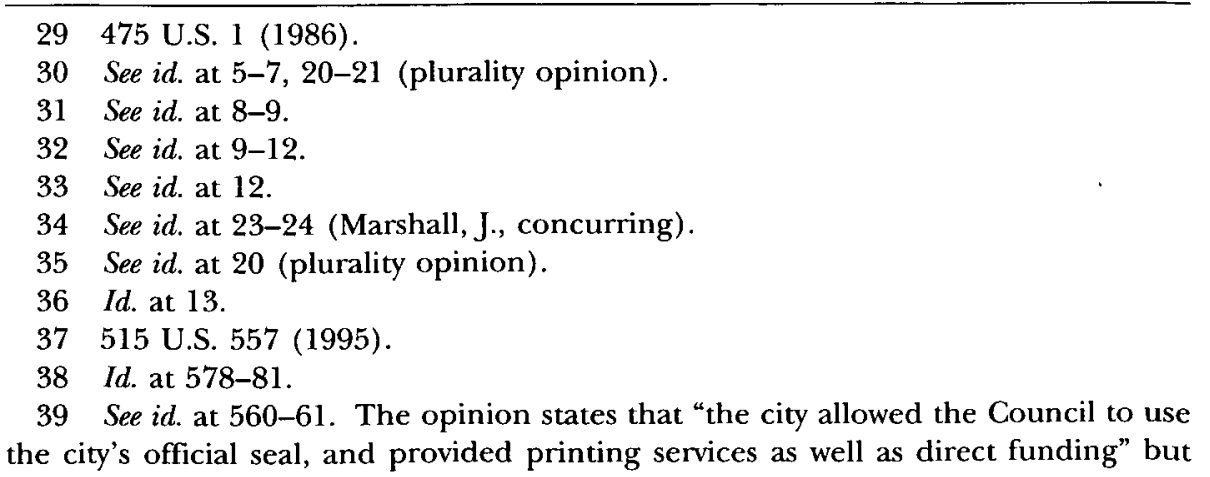


boundaries for the parade were indiscriminate; ${ }^{40}$ in contrast, the gay group presented a focused message. ${ }^{41}$ Yet the Court cast the case as a straightforward instance of government encroachment-in the form of the gay group's reliance on nondiscrimination law-on a private group's "autonomy to control [its] own speech." 42 The Court implicated the gay group's litigation strategy in this public-private alchemy by emphasizing that the group had foresworn any First Amendment claim. ${ }^{43}$ That strategic mistake, however, hardly accounts for the Court's wholesale transformation of a conflict between speakers into a linear narrative of government oppression. ${ }^{44}$ In particular, the Court went far out of its way to romanticize the expressive coherence of the polyglot parade ${ }^{45}$ and to inflate the danger that parade viewers would somehow attribute the gay group's message to the parade organizers' selective process ${ }^{46}$ - even though the organizers exercised little selective judgment about the parade's content and even though most view-

somewhat cryptically notes that the organizers enjoyed those measures of direct support " $[t]$ hrough 1992 "- the year before the specific events that gave rise to the case. Id. at 561. The Court's implication that the parade enjoyed no direct government support in 1993 seems intended to buttress the parade's private status. But even aside from the Court's opaque account of the facts, a momentary strategic shedding of government support should hardly alleviate concerns about the government's role in a nominally private activity, especially when that government support has for many years strengthened the private activity's financial security and public legitimacy.

40 See id. at 562 (citing the trial court's factual findings).

41 See id. at 570 .

42 Id. at 574.

43 See id. at 566 .

44 The Hurley Court also explained its holding in terms of the parade organizers' First Amendment right to expressive association. See id. at 580-81. Subsequently, the Court in Boy Scouts of America v. Dale, 530 U.S. 640 (2000), emphasized the same notion of expressive association to block the application of a state's nondiscrimination law to stop the Boy Scouts from expelling a gay scoutmaster. See id. at 647-61. Earlier expressive association cases had focused on protecting politically unpopular organizations from aggressive government demands for information. See, e.g., NAACP v. Alabama ex rel. Flowers, 377 U.S. 288, 309-10 (1964) (invoking the expressive association principle to bar Alabama from demanding a civil rights organization's membership list). The expressive association doctrine's shift from a means of protecting political outliers to a means of sustaining politically powerful groups' prerogatives parallels the Court's elevation of expressive autonomy interests and rejection of expressive access interests.

45 See Hurley, 515 U.S. at 574 ("Rather like a composer, the Council selects the expressive units of the parade from potential participants, and though the score may not produce a particularized message, each contingent's expression in the Council's eyes comports with what merits celebration on that day.").

46 See id. at 575 (asserting that the gay group's "participation would likely be perceived as having resulted from the Council's customary determination about a unit admitted to the parade"). 
ers would have had little reason to know who the organizers were. ${ }^{47}$ The Court's account of the public-private distinction turned the gay group's expressive interest into a disadvantage, because the group's "public" status transformed its desire for expressive access into government coercion of the "private" parade organizers to deliver an undesired message.

In its journey from Logan Valley to Hurley, the Court transformed expressive property from a public resource that fosters dissident expression into a private preserve that the Constitution shields from dissident expression. ${ }^{48}$ These cases reveal the basic template for the Court's approach to colliding First Amendment interests in every expressive and religious context. The Court initially takes First Amendment access interests very seriously. In subsequent cases it reverses course, using the conceptual primacy of autonomy over access and/or the characterization of access interests as "public" regulatory affronts to deny the constitutional grounding of access interests. On the other side of the cases, the Court grants exclusive constitutional force to the autonomy interests, which it eventually characterizes as expressive, of property owners, whose "private" status secures their rights and relieves them of constitutional obligations. The Court constrains property owners' autonomy interests by deferring to government access mandates in conceptually limited circumstances, averting the need to analyze the relative force of legally grounded expressive access and autonomy interests. In none of the cases, despite their shifts in focus and outcome, does the Court squarely confront the existence of colliding First Amendment interests.

47 See id. at 562 (citing the trial court's findings).

48 Also arguably fitting within this expressive property rubric is a line of decisions in which the Court has protected political parties' associational autonomy to restrict participation in primary elections against efforts to expand the class of eligible primary voters. Compare Clingman v. Beaver, 544 U.S. 581, 591-93 (2005) (rejecting voters' First Amendment challenge to a state's restriction on eligibility to vote in a primary election), with Cal. Democratic Party v. Jones, 530 U.S. 567, 586 (2000) (sustaining parties' First Amendment challenge to a state's expansion of eligibility to vote in a primary election). Reinforcing the autonomy focus of those decisions, which primarily benefit the two major political parties, is the Court's solicitude for state constraints on meaningful access to the political process for minor parties. See, e.g., Timmons v. Twin Cities Area New Party, 520 U.S. 351, 369-70 (1997) (rejecting a minor party's First Amendment challenge to a state's ban on fusion candidacies). For a discussion of party regulation cases prior to Clingman in the context of free speech theory, see Gregory P. Magarian, Regulating Political Parties Under a "Public Rights" First Amendment, 44 WM. \& MARY L. REv. 1939, 2010-60 (2003). 


\section{Media Access Cases}

The most prominent line of expressive access disputes, closely paralleling the expressive property cases, has involved speakers' efforts to gain access to the broadcast and electronic media. In Red Lion Broadcasting Co. v. FCC, ${ }^{49}$ the Court unanimously upheld the federal fairness doctrine, an administrative regulation that required broadcasters to provide a right of reply to anyone criticized over the airwaves, against a radio station's First Amendment challenge. ${ }^{50}$ Justice White's opinion for the Court tacitly embraced the idea of a First Amendment access interest, stating that "[i]t is the right of the public to receive suitable access to social, political, esthetic, moral, and other ideas and experiences which is crucial here"51 and condemning "private censorship." 52 The Red Lion Court, however, did not impose any kind of constitutional access mandate; it simply upheld regulations that provided access. ${ }^{53}$ Thus, the Court's only constitutional holding was that the circumstances of the broadcast industry limited the First Amendment's protection of broadcasters' expressive autonomy. That holding rested on two interlaced features of broadcasting that justified regulation of the industry. First, Justice White suggested that the public's interest in robust debate animated the development of the airwaves and thus logically preceded broadcasters' autonomy interest. ${ }^{54}$ Second, in an argument that echoes the direct attribution of private autonomy to state authority in Logan Valley, ${ }^{55}$ Justice White emphasized that scarcity in the broadcast spectrum rendered broadcasters' property interests in their frequencies contingent and ultimately controllable by the government. ${ }^{56}$

A few years later, a pair of decisions exposed the weak underpinnings of Red Lion. In CBS, Inc. v. Democratic National Committee, ${ }^{57}$ the Court followed Lloyd Corp. in sealing any opening Red Lion might have created for finding a First Amendment right of access to the media.

\footnotetext{
49395 U.S. 367 (1969).

50 See id. at 369-71, 400-01.

51 Id. at 390.

52 Id. at 392.

53 See id. (upholding right of reply regulations as not "inconsistent with the First Amendment goal of producing an informed public capable of conducting its own affairs").

54 See id. at 390 ("It is the right of the viewers and listeners, not the right of the broadcasters, which is paramount.").

55 See supra notes 8-13 and accompanying text.

56 See Red Lion, 395 U.S. at 387-89 (discussing the scarcity rationale for broadcast regulation).

57412 U.S. 94 (1973).
} 
The Democratic Party and a group of business executives opposed to the Vietnam War challenged broadcast networks' bar against selling advertising time for political messages. ${ }^{58}$ Chief Justice Burger's majority opinion emphasized that Congress and the Federal Communications Commission had allowed the bar to stand, reflecting a federal policy of "permit[ting] private broadcasting to develop with the widest journalistic freedom consistent with its public obligations."59 In a key portion of the opinion that garnered only plurality support, Chief Justice Burger argued that the political activists had failed to make the showing of state action necessary for a First Amendment claim. ${ }^{60} \mathrm{His}$ rigid application of the public-private distinction discarded the activists' interest in expressive access to focus completely on the broadcasters' interest in expressive autonomy. Recognizing a right of access "in the name of the First Amendment would be a contradiction," he asserted, because an access right would undermine broadcasters' editorial discretion. ${ }^{61}$ The majority further held, notwithstanding the existing structure of broadcast regulation and the diffuse character of expressive access interests, that an access right would excessively involve the government in determining the content of speech. ${ }^{62}$

The following Term, the Court's decision in Miami Herald Publishing Co. v. Tormillo ${ }^{63}$ squarely rejected the notion of a First Amendment access interest while also limiting the Red Lion allowance for access regulation to the peculiar circumstances of the broadcast industry. The Miami Herald Court struck down a state's requirement that newspapers provide political candidates a right to reply to criticism. ${ }^{64}$ Chief Justice Burger's majority opinion, creating the model for the expressive property cases Pacific Gas and Hurley, categorically denied the existence of any First Amendment access interest, based upon the conviction that any government-mandated access reform would impermissibly undermine the core First Amendment value of expressive autonomy. ${ }^{65}$ The Court placed full constitutional emphasis on the publishers' expressive autonomy interest, manifest in their editorial discretion. ${ }^{66}$ The Court noted but disregarded the argument that newspapers, by virtue of economic conditions, presented barriers to

\footnotetext{
58 See id. at 97-101.

59 Id. at 110.

60 See id. at 114-21 (plurality opinion).

61 Id. at 120-21.

62 See id. at 126-28 (majority opinion)

63418 U.S. 241 (1974).

64 See id. at 243-44, 258.

65 See id. at 254.

66 See id. at 258.
} 
entry tantamount to physical scarcity. ${ }^{67}$ Miami Herald thus left the Red Lion "technological scarcity" argument as a narrow, medium-specific exception to the general rule of media corporations' expressive autonomy.

$C B S$, Inc. v. $F C C^{68}$ demonstrates the Court's recourse to deference in the media access context. Inverting the $C B S v . D N C$ scenario, broadcasters brought a First Amendment challenge against an FCC regulation that required them to sell advertising time to political candidates. ${ }^{69}$ Like the access mandate in PruneYard, the regulation in CBS v. FCC circumvented the Court's denial of a constitutional basis for expressive access interests, thereby seemingly compelling some substantive judicial analysis of the access-autonomy tension. As in PruneYard, however, the Court managed to avoid the issue by purporting to focus on narrow features of the expressive property at issue. The Justices rejected the argument that the FCC regulation impermissibly burdened the broadcasters' editorial discretion, concluding that the regulation "makes a significant contribution to freedom of expression by enhancing the ability of candidates to present, and the public to receive, information necessary for the effective operation of the democratic process."70 The Court, however, emphasized that the regulations created only "a limited right to 'reasonable' access that pertains only to legally qualified federal candidates," 71 and its acknowledgement of the regulation's First Amendment value stopped far short of recognizing an actual First Amendment access right. CBS v. FCC thus solidified the hybrid analysis the earlier media access cases had constructed. As Red Lion had established, the government could choose to impose broadcast access reforms in order to advance the public interest. ${ }^{72}$ However, as CBS $v$. DNC had established, the government was under no First Amendment obligation to do so, ${ }^{73}$ and as Miami Herald had established, broadcast access reforms constituted a limited, medium-specific exception to the prevailing First Amendment concern for media owners' expressive autonomy. ${ }^{74}$

The most recent electronic media access case once again upheld a federal access regulation but sharpened the Court's emphasis on the constitutional primacy of expressive autonomy. In Tumer Broadcasting

67 See id. at 248-51 (discussing the economic scarcity argument).

68453 U.S. 367 (1981).

69 See id. at $371-76$.

70 Id. at 396.

$71 I d$.

72 See supra notes $49-56$ and accompanying text.

73 See supra notes 57-62 and accompanying text.

74 See supra notes 63-67 and accompanying text. 
System, Inc. v. FCC (Tumer II),$^{75}$ the Court upheld federal "must-carry" rules that require cable television systems to allocate space in cable channel arrays to local broadcast stations. ${ }^{76}$ The medium at issue in Tumer, cable, was technologically distinct from broadcasting-and thus, like the newspaper in Miami Herald, not amenable to the Red Lion scarcity rationale. ${ }^{77}$ In addition, the government's must-carry rules benefited a class of content providers rather than opening access for particular speakers. ${ }^{78}$ Based on these factors and a pointedly autonomy-focused statement of First Amendment principles, ${ }^{79}$ the Turner Court applied intermediate scrutiny to ensure that the government had a substantial reason for undermining cable systems' expressive autonomy. ${ }^{80}$ The Court ultimately concluded that the must-carry rules directly advanced several important federal interests, including "promoting the widespread dissemination of information from a multiplicity of sources." 81 The Court's wariness of cable operators' power to close important channels of expression suggests an implicit awareness of access interests. ${ }^{82}$ Neither of the Court's Tumer opinions, however, locates access interests in the First Amendment or addresses the tension between expressive access and expressive autonomy interests. ${ }^{83}$ Instead, the Court sounds a refrain of wary but necessary deference to congressional judgment. ${ }^{84}$ As in Red Lion and CBS v. FCC, but under more stringent review, the Turner Court allowed a limited and

75520 U.S. 180 (1997).

$76 \quad$ Id. at 185.

77 See Turner Broad. Sys., Inc. v. FCC (Tumer I), 512 U.S. 622, 637-40 (1994) (distinguishing Red Lion).

78 See id. at 643-52.

79 "At the heart of the First Amendment lies the principle that each person should decide for himself or herself the ideas and beliefs deserving of expression, consideration, and adherence." Id. at 641 .

80 See id. at 661-64.

81 Turner II, 520 U.S. at 189 (quoting Tumer I, 512 U.S. at 662).

82 See id. at 197 ("Cable operators thus exercise "control over most (if not all) of the television programming that is channeled into the subscriber's home [and] can thus silence the voice of competing speakers with a mere flick of the switch.' " (quoting Tumer I, 512 U.S. at 656)).

83 The Tumer II decision followed Tumer I, which identified intermediate scrutiny as the appropriate standard of review and remanded the case for further proceedings. See Turner I, 512 U.S. at 661-64, 668 .

84 See Turmer II, 520 U.S. at 196 (asserting the heightened importance of deference to Congress "in cases, like this one, involving congressional judgments concerning regulatory schemes of inherent complexity and assessments about the likely interaction of industries undergoing rapid economic and technological change"). 
qualified exception to the First Amendment's protection of expressive autonomy based on special characteristics of the medium at issue. ${ }^{85}$

The media access cases almost exactly parallel the expressive property cases. After initially contemplating the free speech value of access interests, the Court categorically denies any First Amendment right of access to channels of communication while providing a strong right of autonomy for owners of communicative infrastructure. Miami Herald, the print media cousin to the line of electronic media cases, affirms autonomy as the exclusive constitutional value in media access cases, failing to consider how an access interest grounded in the First Amendment might, or might not, mitigate autonomy interests. In the broadcasting and cable contexts, the Court defers to legislative and regulatory access mandates but-as in the expressive property analog, PruneYard-narrowly defines the boundaries in which that discretion may operate. In the media access cases, the Court once again avoids the complication of determining how legally grounded expressive access interests should affect its analysis of expressive autonomy interests.

\section{Copyright Disputes}

Copyright protection facilitates speech by preserving economic incentives to create various kinds of expressive material. ${ }^{86}$ At the same time, copyright protection suppresses speech by providing a legal basis to enjoin publications that infringe copyrights. ${ }^{87}$ In this Article's terms, the incentive to create embodies an autonomy interest, while the desire to use another's intellectual property in one's own expression embodies an access interest. ${ }^{88}$ Unlike the other topics discussed

85 See id.

86 See e.g., Harper \& Row, Publishers, Inc. v. Nation Enters., 471 U.S. 539, 558 (1985) ("[I]t should not be forgotten that the Framers intended copyright itself to be the engine of free expression. . . . [G]opyright supplies the economic incentive to create and disseminate ideas." (citing Twentieth Century Music Corp. v. Aiken, 422 U.S. 151, 156 (1975); Mazer v. Stein, 347 U.S. 201, 209 (1954))).

87 See generally C. Edwin Baker, First Amendment Limits on Copyright, 55 VAND. L. REv. 891, 899-919 (2002) ("[T]he Copyright Clause might be read to [make copying] illegal . . . In each case, however, the individual's expression constitutes speech ....").

88 Rebecca Tushnet makes the inverse analogy: copyright represents a government policy of regulating speech-infringing uses-that would otherwise threaten to drown out the speech copyright protects. See Rebecca Tushnet, Copyright as a Model for Free Speech Law: What Copyright Has in Common with Anti-Pornography Laws, Campaign Finance Reform, and Telecommunications Regulation, 42 B.C. L. REV. 1, 35-37 (2000). She thus compares copyright to regulations of broadcasting and political money, see id. at 60-67, which I associate with access interests, see supra Part I.A.2, infra Part I.A.4. 
in this section, copyright's collision of First Amendment interests is complicated by a constitutional provision outside the First Amendment. The Copyright and Patent Clause authorizes Congress " $[\mathrm{t}] \mathrm{o}$ promote the Progress of Science . . . by securing [to creators] for limited Times . . the exclusive Right to their . . . Writings." 89 The close chronology of the two provisions suggests that a proper reading should give meaningful effect to both.

In a pair of decisions, however, the Justices have rebuffed efforts to place First Amendment limits on copyright. Harper $\mathcal{E}^{2}$ Row, Publishers, Inc. $v$. Nation Enterprises involved a dispute over the initial publication of excerpts from President Gerald R. Ford's memoirs. ${ }^{90}$ Ford's publisher had sold Time the exclusive right to publish excerpts prior to the book's release. ${ }^{91}$ The Nation acquired an advance copy of the book and beat Time to the newsstand, leading Time to cancel its contract with the publisher. ${ }^{92}$ The Nation conceded that it had violated the copyright and that its publication fell outside the recognized boundaries of the "fair use" exception to copyright liability, but it contended that "First Amendment values" compelled a more generous construction of fair use for news reports on matters of public concern. ${ }^{93}$ The Court rejected that position out of hand. ${ }^{94}$ Justice O'Connor's majority opinion emphasized that "the Framers intended copyright itself to be the engine of free expression."95 Accordingly, the Court derided any notion of First Amendment limits on copyright, beyond the longstanding distinction between copyrightable expressions and noncopyrightable ideas, as "fundamentally at odds with the scheme of copyright."96

In Eldred $v$. Ashcroft, ${ }^{97}$ creative users of copyrighted works that had passed into the public domain challenged Congress' twenty-year extension of the duration of copyrights as applied to works under copyright when it was enacted. ${ }^{98}$ In addition to challenging the statute under the Copyright Clause, the plaintiffs contended that the extension, although content-neutral, violated their expressive freedom. ${ }^{99}$

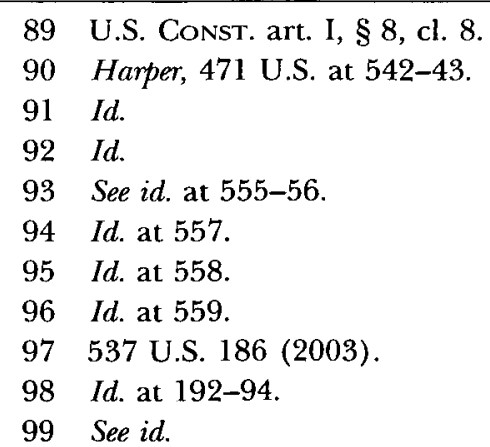


Justice Ginsburg's majority opinion echoed Harper, characterizing the Copyright and Patent Clause as not merely compatible with but supportive of expressive freedom. ${ }^{100}$ The Eldred Court tacitly acknowledged the First Amendment authority for the plaintiffs' challenge, creating an opening for a forthright analysis of the colliding autonomy and access interests. Justice Ginsburg, however, sealed the opening, holding that, to whatever extent copyright restrictions implicated First Amendment concerns, "copyright's built-in free speech safeguards are generally adequate to address them."101 The safeguards she identified were the same statutory constraints on copyright discussed in Harper. the expression-idea distinction and the fair use doctrine. ${ }^{102}$

The speech-copyright decisions, like Lloyd Corp. and Miami Herald, deny the existence of a First Amendment interest in expressive access while holding that the First Amendment necessarily and exclusively protects expressive autonomy. The Court's equation of copyright with free speech, like its analysis in the recent expressive property cases, effectively transforms a property interest into an expressive autonomy interest. ${ }^{103}$ The copyright cases stack deference atop the denial, in that Congress-by extending only a limited fair use exemption to copyright liability in Harper ${ }^{104}$ and extending the term of copyright protection in Eldred ${ }^{105}$ - has used its copyright power to advance expressive autonomy while constraining expressive access. By the same token, the Court's acknowledgement of the expression-idea distinction and the fair use doctrine roughly parallels its deference in PruneYard and CBS v. FCC to limited regulatory constraints on expressive autonomy. Rather than performing even a cursory analysis of how the First Amendment's protections constrain or shape congressional copyright authority, the Court simply reads the Copyright and Patent Clause as embodying the interest in expressive autonomy and subsuming the interest in expressive access. ${ }^{106}$

100 See id. at 219 (citing Harper, 471 U.S. at 558).

101 See id. at 221.

102 See id. at 219-20.

103 See supra notes 21-48 and accompanying text.

104 See Harper, 471 U.S. at 555-60.

105 See Eldred, 537 U.S. at 222.

106 The Court's strong pull toward deference in the copyright area-the one expressive access context that entails a conflict between two distinct provisions of the constitutional text-anticipates the Court's ultimate arrival at an extremely deferential approach to the problem of religious accommodation, where textually grounded free exercise and nonestablishment interests collide. See infra Part I.B.3.a-b. 


\section{Campaign Finance Challenges}

The problem of campaign finance regulation presents a variation on the collision between expressive access and expressive autonomy interests. Campaign finance limits do not provide putative speakers literal access to expressive property. Instead, campaign finance limits constrain the use of expressive property in order, among other goals, to alleviate economic disparities between unequally funded speakers' capacities to participate in, and influence, political debate. ${ }^{107}$ The fundamental clash of expressive interests remains the same as in other expressive access cases: proponents of limits on political money seek to secure access to political discourse for underfinanced speakers, while opponents seek to preserve the expressive autonomy of speakers who possess the means to spend money. In this area the Court again has rejected the notion of a First Amendment access interest and has strongly vindicated the expressive autonomy of property holdersparties, candidates, and "independent" entities with enough money to influence electoral debate. ${ }^{108}$ To the extent the Court has allowed constraints on expressive autonomy, it has conceptually limited the range within which those constraints may operate and has left their definition to legislatures. ${ }^{109}$

The full narrative of the Court's approach to colliding expressive interests in the campaign finance context, from denial to deference, emerges from Buckley $v$. Valeo. ${ }^{10}$ Entities that wanted to contribute and spend money in political campaigns without any constraint challenged, as violations of their First Amendment autonomy interests, provisions of the Federal Election Campaign Act (FECA) Amendments of 1974111 that limited the amounts of money anyone could contribute to a federal campaign and the amounts candidates and independent entities could spend in the course of a campaign. ${ }^{112}$

107 See, e.g., J. Skelly Wright, Money and the Pollution of Politics: Is the First Amendment an Obstacle to Political Equality?, 82 Colum. L. Rev. 609, 638-42 (1982); see also Colo. Republican Fed. Campaign Comm. v. FEC (Republican I), 518 U.S. 604, 649-50 (1996) (Stevens, J., dissenting) (noting that "[i]t is quite wrong to assume that the net effect of limits on contributions and expenditures . . . will be adverse to the interest in informed debate protected by the First Amendment," because those limits "tend to protect equal access to the political arena").

108 See infra notes $110-124$ and accompanying text.

109 See infra notes 110-124 and accompanying text.

110424 U.S. 1 (1976) (per curiam).

111 Pub. L. No. 93-443, $\S \S 101$ (a)-(e), 202, 210, 88 Stat. 1263, 1263-67, 1257-76, $1288-89$ (1974) (current version at 18 U.S.C. $\$ \S 608,609$ (2000) and 2 U.S.C. $\$ \S 422$, 437 (2000 \& Supp. 2004)).

112 See Buckley, 424 U.S. at 11. 
One theory of the provisions' constitutionality was that finance regulations prevented moneyed interests in political campaigns from silencing and marginalizing ordinary citizens of modest means-effectively an expressive access argument. ${ }^{113}$ The Buckley Court struck down the FECA expenditure limits while upholding the contribution limits. ${ }^{114}$ The Court's distinction between expenditures and contributions turned on the different degrees of expressive autonomy it saw at stake. ${ }^{115}$ Campaign expenditures, the Court explained, deserve the fullest degree of First Amendment protection because they allow speakers to inject expression directly into the electoral process. ${ }^{116}$ In contrast, campaign contributions communicate the contributor's support for a candidate or cause, but increasing the amount of a contribution adds only marginally to that message. ${ }^{117}$

In striking down the various FECA expenditure limits, the Court once again denied the idea of a First Amendment access interest while locating expressive autonomy at the heart of the First Amendment. The Court dismissed the "equalization rationale" for campaign finance regulation - the contention that expenditure limits were necessary, or at least permissible, to give people of lesser means a reasonable opportunity to influence political debate-by proclaiming that "the concept that government may restrict the speech of some elements of our society in order to enhance the relative voice of others is wholly foreign to the First Amendment."118 The Court gave no consideration to the equalization rationale's own speech-protective underpinnings in a theory of access rights. The Court's denial of the access interest in campaign finance controls implicitly depended on rigid application of the public-private distinction. The Court discerned no cognizable claim of right to campaign finance limits because it saw in the access provision only a governmental regulation and not the expressive interests the regulation served. At the same time, the Court classified officeholders, office seekers, and powerful political organizations as purely private rights holders entitled to full expressive autonomy. ${ }^{119}$ In letting stand what it saw as the contribution limits' lesser threat to expressive autonomy, the Court-as in PruneYard and CBS v. FCC-deferred to Congress' prioritization of expressive and regulatory values, albeit with only the prevention of

$\begin{array}{ll}113 & \text { See id. at 25-26. } \\ 114 & \text { Id. at 58-59. } \\ 115 & \text { See id. at 20-23. } \\ 116 & \text { See id. at 19-20. } \\ 117 & \text { See id. at 20-22. } \\ 118 & \text { Id. at 48-49. } \\ 119 & \text { See id. at 19-20. }\end{array}$


corruption, and not the equalization of opportunities to influence political discourse, as an acceptable regulatory justification. ${ }^{120}$ Mirroring those other deferential cases, the Court's peculiar explanation of campaign contributions' lesser value for expressive autonomy ensured that its grounds for upholding the contribution limits would not translate into other areas of campaign finance regulation.

On occasion the Court has suggested limits to the expressive autonomy inherent in political expenditures, ${ }^{121}$ while a recent decision held that even contribution limits can become unconstitutionally draconian. ${ }^{122}$ The essential structure of Buckley, however, has weathered three decades, and the Court has expressly reaffirmed the Buckley distinction between constitutional approaches to expenditure and contribution limits. ${ }^{123}$ Although almost everyone finds that distinction doctrinally unpersuasive, normatively undesirable, and/or practically pernicious, ${ }^{124}$ it makes perfect sense in the context of the Court's other expressive access decisions. Once again the Court strongly affirms the First Amendment primacy of the interest in expressive autonomy; denies the idea of a competing First Amendment interest in expressive access; and avoids confronting the substantive tension between access and autonomy interests by deferring to government access regulations in what the Justices portray as a conceptually limited sphere of diminished expressive autonomy.

\section{The Press vs. Privacy: Bartnicki v. Vopper}

In one recent decision, the Court squarely acknowledged a conflict between First Amendment principles that correspond with access and autonomy interests. Bartnicki $v$. Vopper ${ }^{125}$ presented the question whether the First Amendment protected a radio commentator's broadcast of a sensitive cellular telephone conversation-which the commentator had not himself intercepted but had reason to know had been intercepted unlawfully-between the president of a

120 See id. at 26-27 (accepting the anticorruption rationale for contribution limits).

121 See McConnell v. FEC, 540 U.S. 93, 224 (2003) (upholding federal limits on expenditures of "soft money" and certain expenditures for issue advertisements); Austin v. Mich. State Chamber of Commerce, 494 U.S. 652, 668-69 (1990) (upholding a ban on expenditures of corporate treasury funds in election campaigns).

122 See Randall v. Sorrell, 126 S. Ct. 2479, 2500 (2006) (plurality opinion).

123 See Nixon v. Shrink Mo. Gov't PAC, 528 U.S. 377, 386-88 (2000).

124 See, e.g., Burt Neuborne, One Dollar-One Vote: A Preface to Debating Campaign Finance Reform, 37 WASHBURN L.J. 1, 29-30 (1997) (summarizing the arguments against the contribution-expenditure distinction).

125532 U.S. 514 (2001). 
teacher's union and the union's negotiator in a highly contentious and well-publicized labor dispute. ${ }^{126}$ Justice Stevens, writing for the majority, characterized the case as presenting "a conflict between interests of the highest order-on the one hand, the interest in the full and free dissemination of information concerning public issues, and, on the other hand, the interest in individual privacy and, more specifically, in fostering private speech." 127 Bartnicki did not involve the sort of straightforward access interest present in the expressive property, media access, and copyright cases, where putative speakers sought to use privately owned channels of communication to express their own messages. Rather, like the campaign finance cases, Bartnicki involved diminution of one speaker's expressive property-the personal privacy that fosters private speech-in order to enhance another speaker's expressive opportunity. ${ }^{128}$ In affirming the radio commentator's constitutional immunity from prosecution, the Court emphasized that "privacy concerns give way when balanced against the interest in publishing matters of public importance." 129

The Bartnicki majority's acknowledgement and resolution of the conflict between informational and privacy concerns amounts to the Court's most thoughtful and candid analysis of the tension between expressive access and autonomy interests. Even here, however, the discussion only scrapes the surface of the problem. Justice Stevens' elevation of speech about matters of public concern helpfully suggests a priority of First Amendment values. ${ }^{130}$ His opinion, however, does not explain how the competing interests in the case-facilitation of private discussion and dissemination of information-serve that paramount value. Instead, the opinion simply accords the informational interest a categorical trump over the privacy interest, ${ }^{131}$ effectively inverting but not deepening the typical public-private analysis of cases such as Hurley. The opinion is especially unsatisfying because the expressive privacy interest at issue in Bartnicki strikes closer to the integrity of natural persons, and thus arguably carries greater weight, than the sorts of institutional expressive property at issue in other expressive access disputes. The opinion also fails to flesh out why and to what extent First Amendment doctrine should prioritize the dissemination of information about matters of public concern. Finally, the opinion does nothing to enhance the Court's broader cognizance

126 See id. at 517-19.

127 Id. at 518.

128 See id. at 533-35.

$129 I d$. at 534.

130 See id. at 534-35.

131 See id. 
of colliding First Amendment interests. Rather than situating the case in the context of the many decisions that have ignored or dodged the presence of colliding speech interests, the Court treats Bartnicki as a sui generis dispute. ${ }^{132}$

All of the Supreme Court's expressive access decisions reveal a common analytic methodology for dealing with colliding First Amendment interests. The Court recognizes a strong free speech autonomy interest. It denies the notion of a free speech access interest as entirely outside the First Amendment, placing the potentially competing interests on opposite sides of the rigid public-private distinction and touting the conceptual primacy of autonomy as a basis for First Amendment protection. On the infrequent occasions when the Court allows access interests to encroach on autonomy protections, it defers to elected officials' discretion, rather than invoking the First Amendment's mandate, and limits the encroachment to narrowly defined conditions. This combination of denial and deference allows the Court, in case after case, to avoid substantive consideration of the colliding First Amendment interests that expressive access cases present.

\section{B. The Free Exercise Clause vs. the Establishment Clause: Religious Accommodation Decisions}

The Supreme Court has confronted a substantial series of cases in which religious believers invoke the Free Exercise Clause to claim exemptions from the application of generally applicable laws. ${ }^{133}$

132 Justice Breyer's concurring opinion in Bartnicki provides a more extensive analysis than the majority's of the First Amendment collision and connects the case with First Amendment collisions in the media access and campaign finance settings. See id. at 536 (Breyer, J., concurring) (citing Nixon v. Shrink Mo. Gov't PAC, 528 U.S. 377, 402 (2000) (Breyer, J., concurring); Turner Board. Sys., Inc. v. FCC (Tumer II), 520 U.S. 180, 227 (1997) (Breyer, J., concurring in part)). Justice Breyer, however, makes almost no effort to parse the underlying values at stake. Instead, he suggests a vaguely formulated balancing of a statute's "speech-restricting and speech-enhancing consequences," id. at 536, and then offers a balancing analysis that focuses on privacy expectations rather than speech interests, see id. at 538-40. Justice Breyer's approach to the case reinforces the sense that the decision lacks broader applicability. See id. at 540 (urging a narrow reading of the Court's decision). He also evokes PruneYard and $C B S$ v. FCC by urging broad deference to legislative judgment. See id. at 541 ("[W]e should avoid adopting overly broad or rigid constitutional rules, which would unnecessarily restrict legislative flexibility."). Justice Breyer's earlier opinion in Tumer II, while more explicit about the nature of the competing First Amendment interests at stake, takes a similarly imprecise and deferential approach to balancing those interests. See Tumer II, 520 U.S. at 227-29 (Breyer, J., concurring in part).

133 The chronological scope of my discussion begins with Sherbert $v$. Verner, 374 U.S. 398 (1963), the first case to announce a robust doctrine of religious accommodation. See id. at 402-03. Earlier decisions that anticipated the accommodation issue 
These disputes, known as religious accommodation cases, differ descriptively from cases in which religious believers invoke the Free Exercise Clause against alleged religious discrimination. The Court has made clear that the Free Exercise Clause prohibits the government from going out of its way to target religious believers or institutions for special burdens. ${ }^{134}$ Free Exercise accommodation cases pose a more conceptually challenging question: when must the government go out of its way to excuse religious believers from burdens applied generally to all citizens? ${ }^{135}$ One complication in this analysis is that when government goes out of its way to confer a benefit on religion, it raises a concern under any forceful account of the Establishment Clause by according favorable treatment to religion or religious believers. ${ }^{136}$ Thus, religious accommodation cases set the Free Exercise Clause against the Establishment Clause.

In the religious accommodation context, as in the expressive access context, the Court finds a way to avoid the collision of First Amendment interests. The Court takes remarkably similar approaches in the two areas, once again employing in religious accommodation disputes the techniques of denial and deference. The principal difference between the speech and religion settings is that the textual anchors of the competing Religion Clause interests

include Prince $v$. Massachusetts, 321 U.S. 158, 169-71 (1944) (upholding the application against Jehovah's Witnesses of a state prohibition on child labor they considered a religious obligation); Cantwell v. Connecticut, 310 U.S. 296, 309-11 (1940) (striking down the conviction of a religious speaker for inciting a breach of the peace under free speech and free exercise principles); Pierce v. Society of Sisters, 268 U.S. 510, 534-36 (1925) (sustaining religious educators' challenge to a mandatory public education statute under due process and free exercise principles); and Reynolds $v$. United States, 98 U.S. 145, 161, 166-68 (1878) (upholding the application of a federal bigamy prohibition against a polygamous Mormon).

134 See Church of the Lukumi Babalu Aye, Inc. v. City of Hialeah, 508 U.S. 520, 543 (1993). Religious discrimination cases do not pit free exercise against Establishment Clause interests; if anything, government discrimination against one belief system may reflect favor for another system and thus violate both First Amendment principles.

135 The issue of religious accommodation has inspired a formidable body of academic literature. An excellent introduction is the nuanced debate between Ira C. Lupu, The Trouble with Accommodation, 60 GEO. WASH. L. REv. 743 (1992), and Michael W. McConnell, Accommodation of Religion: An Update and a Response to the Critics, 60 Geo. WASH. L. Rev. 685 (1992).

136 Elsewhere I have considered the issue of religious accommodation under a strongly separationist account of the Establishment Clause. See Gregory P. Magarian, Hox: To Apply the Religious Freedom Restoration Act to Federal Law Without Violating the Constitution, 99 Мich. L. Rev. 1903, 1970-72 (2001). The analysis in the present Article comports with any Establishment Clause theory that takes seriously the possibility that religious accommodations might undermine nonestablishment interests. 
render denial of either interest unsustainable. Accordingly, the Court has opted to marginalize both free exercise and nonestablishment concerns in accommodation cases, in an especially strong show of deference. The Court lets both Religion Clauses operate within their separate spheres but abdicates to elected officials the responsibility for assessing the competing interests their collision in accommodation scenarios presents. ${ }^{137}$ This section will discuss the Court's approach to religious accommodation cases by following a spectrum from the cases in which the Court most clearly acknowledges constitutional free exercise interests to present accommodation doctrine, which reduces the First Amendment to a virtual dead letter.

\section{Mandatory Accommodation Cases}

Mandatory accommodation cases involve claims by religious believers that the Free Exercise Clause compels government to accommodate them by exempting them from laws of general application. When the Court granted mandatory accommodations, it avoided analysis of the free exercise-nonestablishment collision by giving strong effect to the Free Exercise Clause while denying any meaningful effect to the Establishment Clause. When the Court struck down mandatory accommodations, it conversely gave strong effect to the Establishment Clause while denying any meaningful effect to the Free Exercise Clause. The conceptual difficulty of denying effect to textually grounded constitutional provisions, along with the practical difficulty of reconciling the results in various successful and unsuccessful mandatory accommodation cases, may explain why the Court subsequently has employed an extreme brand of deference to nullify the doctrine of mandatory accommodation. ${ }^{138}$

\section{a. Mandatory Accommodations Granted}

In a relatively narrow but important range of mandatory accommodation cases, the Court prior to 1990 held that the Free Exercise Clause required accommodations. The leading decision was Sherbert $v$. Verner, ${ }^{139}$ which barred a state from denying unemployment benefits to a worker who had refused a job on the ground that it would have required her to work on Saturdays, violating her Seventh-Day Adventist convictions. ${ }^{140}$ The Court in Sherbert declared that it would

137 See infra Part I.B.3.a-b.

138 See infra Part I.B.3.a-b.

139374 U.S. 398 (1963).

140 See id. at 409-10. 
apply strict scrutiny to mandatory accommodation claims. ${ }^{141}$ Writing for the majority, Justice Brennan purported to distinguish-but as Justice Stewart pointed out in his opinion concurring in the judgment, tacitly overruled ${ }^{142}$ - the Court's recent decision in Braunfeld $v$. Brown, ${ }^{143}$ which had upheld a state's mandatory Sunday closing law against a free exercise challenge brought by orthodox Jewish merchants. ${ }^{144}$ Braunfeld had justified the Sunday closing law as a mere "indirect burden" 145 on the Jewish merchants' observation of the Saturday Sabbath that advanced a substantial state interest in maintaining a uniform day of rest. ${ }^{146}$ The Sherbert Court, in contrast, found the state's more concrete interest in preventing fraud and abuse in the unemployment compensation system insufficient to overcome the arguably less direct burden that denial of unemployment compensation imposed on the Seventh-Day Adventist's religious observance. ${ }^{147}$ Justice Brennan acknowledged the potential Establishment Clause dimension of creating a special legal exemption for particular religious believers but shrugged off the problem. ${ }^{148}$ The Court dryly noted that "plainly we are not fostering the 'establishment' of the Seventh-day Adventist religion in South Carolina"; rather, the Court was simply upholding "the governmental obligation of neutrality in the face of religious differences." 149 Justice Stewart strongly criticized the majority's failure to confront what he considered an undeniable collision between the Free Exercise Clause and the Court's Establishment Clause precedents. ${ }^{150}$

The strict scrutiny standard Sherbert announced for mandatory accommodation claims grew notoriously short legs. The Court applied strict scrutiny to sustain mandatory accommodation claims in three subsequent unemployment benefits cases-Thomas $v$. Review Board, ${ }^{151}$ Hobbie v. Unemployment Appeals Commission, ${ }^{152}$ and Frazee $v$.

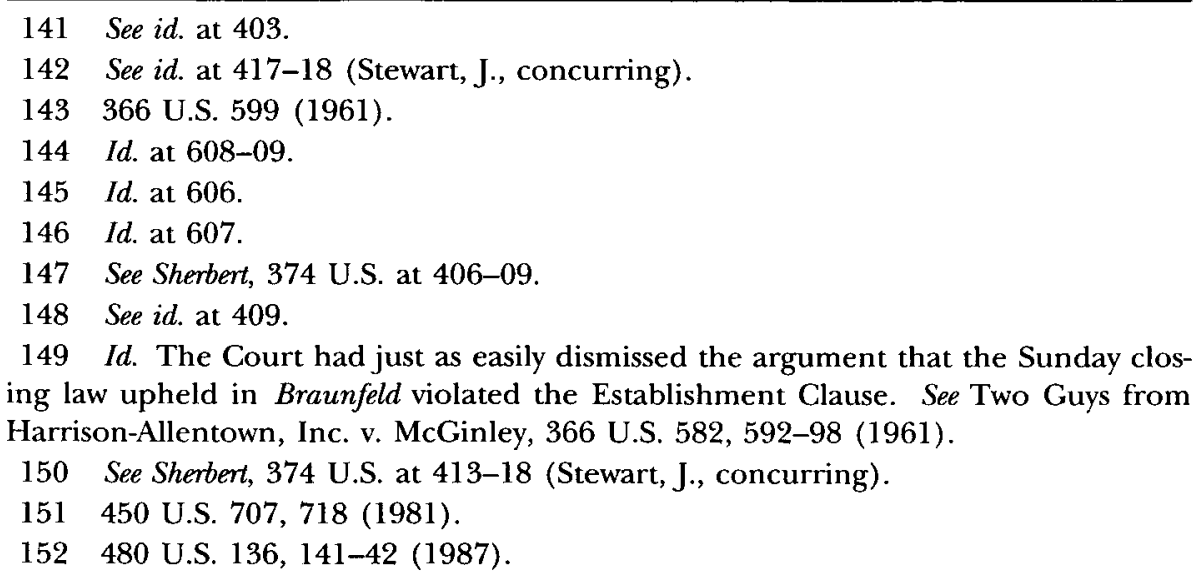


Illinois Department of Employment Security ${ }^{153}$ - that were materially indistinguishable from Sherbert. Those decisions simply reiterated the Sherbert Court's disavowal of any substantial tension between the Free Exercise Clause imperative to grant accommodation and the Establishment Clause imperative not to show special favor to religion. ${ }^{154}$ The only other case in which the Court mandated an accommodation was Wisconsin v. Yoder. ${ }^{155}$ The Court there rejected Wisconsin's attempt to enforce its compulsory student attendance law against members of the Old Order Amish religion. ${ }^{156}$ As befits an idiosyncratic decision, Chief Justice Burger's opinion for the majority adopted a quirky tone of sentimental solicitude for the Amish way of life. ${ }^{157}$ Even so, the Court again justified its decision in terms of a "constitutional requirement for governmental neutrality"158 whose salience for the dispute the Court treated as self-evident. As in Sherbert, the Court acknowledged "the danger that an exception from a general obligation of citizenship on religious grounds may run afoul of the Establishment Clause."159 Once again, however, it dismissed that danger-without any further analysis-in order to pursue "the protection of values promoted by the right of free exercise." 160

These cases, in which the Court found compelling grounds to believe the Free Exercise Clause exempted religious believers from generally applicable legal obligations, provided ideal opportunities to explain how and why the particular free exercise interests at issue should trump the establishment concerns such exemptions raise. The Court, however, passed up those opportunities, willfully ignoring the cases' Establishment Clause dimensions. In this respect, the successful mandatory accommodation cases resemble expressive access decisions such as Lloyd Corp. and Miami Herald, in which the Court

153489 U.S. 829, 835 (1989).

154 See Hobbie, 480 U.S. at 144-45 (quoting Sherbert, 374 U.S. at 409); Thomas, 450 U.S. at 719-20 (same). The Hobbie Court elaborated slightly on the Sherbert Court's basis for ignoring Establishment Clause concerns, noting that "provision of unemployment benefits to religious observers does not single out a particular class of such persons for favorable treatment and thereby have the effect of implicitly endorsing a particular religious belief." Hobbie, 480 U.S. at 145 n.11.

155406 U.S. 205, 234-36 (1972).

156 Id. at 234-36.

157 See, e.g., id. at 210 (explaining Amish communities' objection to formal education in terms of "their devotion to a life in harmony with nature and the soil, as exemplified by the simple life of the early Christian era that continued in America during much of our early national life").

158 Id. at 220.

159 Id. at $220-21$.

$160 I d$. at 221. 
sustained expressive autonomy claims while rejecting out of hand any constitutional interest in expressive access. ${ }^{161}$ The text of the Religion Clauses precluded the Court in Sherbert and Yoder from directly following the course of those speech cases and denying outright the constitutional stature of the nonestablishment interest. The Court, however, could and did disavow any role in these cases for the Establishment Clause.

\section{b. Mandatory Accommodations Denied}

Notwithstanding the strict scrutiny standard of Sherbert, the far more common result in mandatory accommodation cases was for the Court to deny the accommodation claims. The Court used several different analytic techniques to reach these seemingly unlikely results, but in none of the decisions did it consider whether and to what extent the Establishment Clause placed constraints on the cognizable range of mandatory accommodations. Instead, the Court simply deferred to discretionary government decisions not to accommodate, effectively rendering both the Free Exercise Clause and the Establishment Clause irrelevant.

The Court ruled for the government in some mandatory accommodation cases by taking a restrictive view of what constituted a sufficiently weighty burden on free exercise to trigger the Sherbert strict scrutiny analysis. In Tony $\mathcal{F}^{\mathcal{O}}$ Susan Alamo Foundation v. Secretary of Labor, ${ }^{162}$ the federal government sought to impose the minimum wage and recordkeeping requirements of the Fair Labor Standards Act on a religious foundation whose ministry to convicts and drug addicts included having them do unpaid work in the Foundation's commercial businesses. ${ }^{163}$ The Foundation insisted that its specific method of dealing with its charges was integral to its religious mission, but the Court determined that the Foundation could satisfy the Act consistently with its religious convictions. ${ }^{164}$ While minimizing the claimants' free exercise interest, Justice White's majority opinion made no mention of the possibility that allowing a religious organization's commercial businesses to flout federal employment standards might violate the Establishment Clause. ${ }^{165}$ Similarly, a plurality in Bowen $v$.

\footnotetext{
161 See supra notes 14-17, 63-67 and accompanying text.

162471 U.S. 290 (1985).

163 See id. at 292-93.

164 See id. at 303-05.

165 The opinion's only Establishment Clause analysis was its rejection of the Foundation's claim that the Act's recordkeeping requirements would impermissibly entangle the government with religion. See id. at 305-06.
} 
Roy ${ }^{166}$ all but mocked a Native American family's free exercise claim that requiring them to furnish a social security number for their daughter in order to receive welfare benefits would compromise their spiritual control over their lives while completely ignoring the Establishment Clause as a potential ground for denying the claim. ${ }^{167}$

In another group of cases, the Court found the government's asserted regulatory interests sufficiently strong to overcome any burden the challenged government actions imposed on free exercise. In United States v. Lee, ${ }^{168}$ Chief Justice Burger reached the apparent limits of his fondness for the Old Order Amish, ${ }^{169}$ writing a majority opinion that rejected an Amish employer's argument that paying social security taxes would contradict his religious duty to provide social relief independent of the government. ${ }^{170}$ The Court found "the broad public interest in maintaining a sound tax system" too important to compromise in the name of religious freedom. ${ }^{171}$ Bob Jones University $v$. United States ${ }^{172}$ found the Court sustaining the government's denial of tax-exempt status to a university that engaged in religiously motivated racial discrimination. ${ }^{173}$ Although acknowledging the burden that taxation would place on the school, the Court subordinated that burden to the government's compelling interest in eradicating racial discrimination in education. ${ }^{174}$ In Lyng $v$. Northwest Indian Cemetery Protective Ass' $n,{ }^{175}$ the Court rejected an effort to block timber harvesting in a forest area that Native Americans used for religious rituals. ${ }^{176}$ Justice O'Connor's majority opinion declined even to apply strict scrutiny, holding that the requested accommodation would impermissibly interfere with the government's conduct of its internal affairs ${ }^{177}$-an analysis the majority portion of the Court's opinion in Bowen had also applied to the government's requirement that the Native American

\footnotetext{
166476 U.S. 693 (1986).

168455 U.S. 252 (1982). accompanying text.

170 See Lee, 455 U.S. at 260-61.

171 Id. at 260.

172461 U.S. 574 (1983).

173 See id. at 612.

174 See id. at 603-04.

175485 U.S. 439 (1988).

176 See id. at 451-53.

177 See id. at 447-50.
}

167 See id. at 703-04 (plurality opinion).

169 Cf. Wisconsin v. Yoder, 406 U.S. 205, 210, 234-36 (1972) (holding, after favorably describing the Amish's simple way of life, that a compulsory student attendance law violated the free exercise rights of Old Order Amish); supra notes 155-60 and 
family maintain a social security number. ${ }^{178}$ At no point in rejecting any of these free exercise claims did the Court assess the possible import of the Establishment Clause for the requested accommodations.

In a final set of cases, the Court determined that the government's pressing need to control prison and military environments categorically precluded application of the Sherbert strict scrutiny standard to accommodation claims brought by prisoners and service members. In O'Lone v. Estate of Shabazz, ${ }^{179}$ the Court applied a deferential "reasonableness" standard of review to uphold federal prison policies that prevented Muslim inmates from attending weekly Jumu'ah congregational services. ${ }^{180}$ Although the services represented a critical aspect of the Muslim prisoners' religious obligations, the Court went out of its way " $[\mathrm{t}] \mathrm{o}$ ensure that courts afford appropriate deference to prison officials" in connection with "evaluation of penological objectives." 181 Similarly, in Goldman $v$. Weinberger, ${ }^{182}$ the Court upheld the application of a military regulation to bar a Jewish officer in the Air Force from wearing a yarmulke while in uniform. ${ }^{183}$ Once again, the majority acknowledged the importance to the officer of his religious practice but focused its attention on the government's pressing institutional interests, emphasizing that "[o] ur review of military regulations challenged on First Amendment grounds is far more deferential than constitutional review of similar laws or regulations designed for civilian society."184 Once again, the Court gave no consideration to the Establishment Clause as a reason to avoid special exemptions for religious believers. ${ }^{185}$

All of these denials of mandatory accommodations provided a context in which the Court could have measured the requirements of the Free Exercise Clause against the limitations of the Establishment Clause. The decisions, however, rejected the free exercise grounding of the accommodation claims while ignoring any establishment con-

\footnotetext{
178 See Bowen v. Roy, 476 U.S. 693, 699-700 (1986).

179482 U.S. 342 (1987).

180 See id. at $346-47,349$.

181 Id. at 349.

182475 U.S. 503 (1986).

183 See id. at 509-10.

184 Id. at 507.

185 Justice Stevens wrote separately in Goldman to emphasize "the interest in uniform treatment for the members of all religious faiths." Id. at 512 (Stevens, J., concurring). He maintained that, although a yarmulke may be an especially physically unobtrusive religious symbol, any attempt to make practical distinctions between accommodating a yarmulke and Rastafarian dreadlocks or a Sikh turban would impermissibly involve the government in religious distinctions. See id. at 512-13.
} 
cerns the requested accommodations might have raised. The Sherbert mandate of strict scrutiny for free exercise accommodation claims renders both sides of this First Amendment denial extremely puzzling. On one hand, the Court seemingly should have taken the Free Exercise Clause more seriously as a source of accommodation claims. On the other hand, the Establishment Clause could have-perhaps should have-provided the Court with a textually anchored constitutional counterweight to the Sherbertfortified Free Exercise Clause in cases where granting an accommodation would have required the government to distribute an important prerogative inequitably between religious believers and nonbelievers. Instead, however, the Court in these cases opted to imbue government regulatory interests with greater force than they have ever enjoyed in any other arena where the Court applies strict scrutiny, overwhelming the asserted free exercise interests while rendering establishment concerns irrelevant. As such, these cases resemble deferential free speech decisions such as PruneYard and CBS v. FCC, in which the Court subordinated a seemingly significant First Amendment interest not to a contrary First Amendment interest, but rather to the government's regulatory priorities. ${ }^{186}$

\section{Permissive Accommodation Cases}

In the permissive accommodation scenario, the government chooses to grant an accommodation to religious believers, and nonbeneficiaries challenge the grant under the Establishment Clause. The Court's use of denial and deference in these cases produced mixed outcomes prior to 1990. In the cases that upheld permissive accommodations against Establishment Clause challenges, the Court intimated connections between the accommodations and strong free exercise interests-but carefully avoided actual reliance on the Free Exercise Clause-while denying the salience of the claimed nonestablishment interests. Conversely, in the cases that struck down permissive accommodations under the Establishment Clause, the Court denied the salience of the free exercise interests claimed to defend the accommodations.

\section{a. Permissive Accommodations Upheld}

In Walz v. Tax Commission, ${ }^{187}$ the Court upheld a New York City tax exemption for religious property, authorized by a state constitu-

186 See supra notes 21-28, 68-71 and accompanying text.

187397 U.S. 664 (1970). 
tional provision that preserved exemptions for property " "used exclusively for religious, educational or charitable purposes." 188 Chief Justice Burger began his discussion with perhaps the Court's most forthright acknowledgement of the tension between the Establishment and Free Exercise Clauses, "both of which are cast in absolute terms, and either of which, if expanded to a logical extreme, would tend to clash with the other."189 His prescription, however, was to find "play in the joints" between the two clauses, ${ }^{190}$ and the analysis that followed ran headlong from the implications of both. Religious accommodations, the Walz Court declared, reflect the inescapable truth that " $[\mathrm{g}]$ ]overnments have not always been tolerant of religious activity," 191 but the Free Exercise Clause itself mandates no more than "noninterference" with religion. ${ }^{192}$ On the other side, nonestablishment represents a serious constitutional policy with deep historical roots, ${ }^{193}$ but letting churches operate free of the obligations others must bear merely establishes a minimal level of "benevolent neutrality toward churches and religious exercise generally." 194 Walz validated substantial government financial accommodation of activities critical to many people's religious worship. ${ }^{195}$ Yet, according to the Supreme Court, the two constitutional provisions that speak directly to the delicate relationship between government and religion have nothing to do with that result. ${ }^{196}$

The Court in Corporation of the Presiding Bishop of the Church of Jesus Christ of Latter-Day Saints v. Amos ${ }^{197}$ upheld the application to a church's secular nonprofit activities of a federal law that exempted religious employers from prohibitions on religious employment discrimination. ${ }^{198}$ The Court did not reach the question of whether the Free Exercise Clause required the exemption, ${ }^{199}$ and Justice White's majority opinion relied heavily on the Walz "play in the joints" formu-

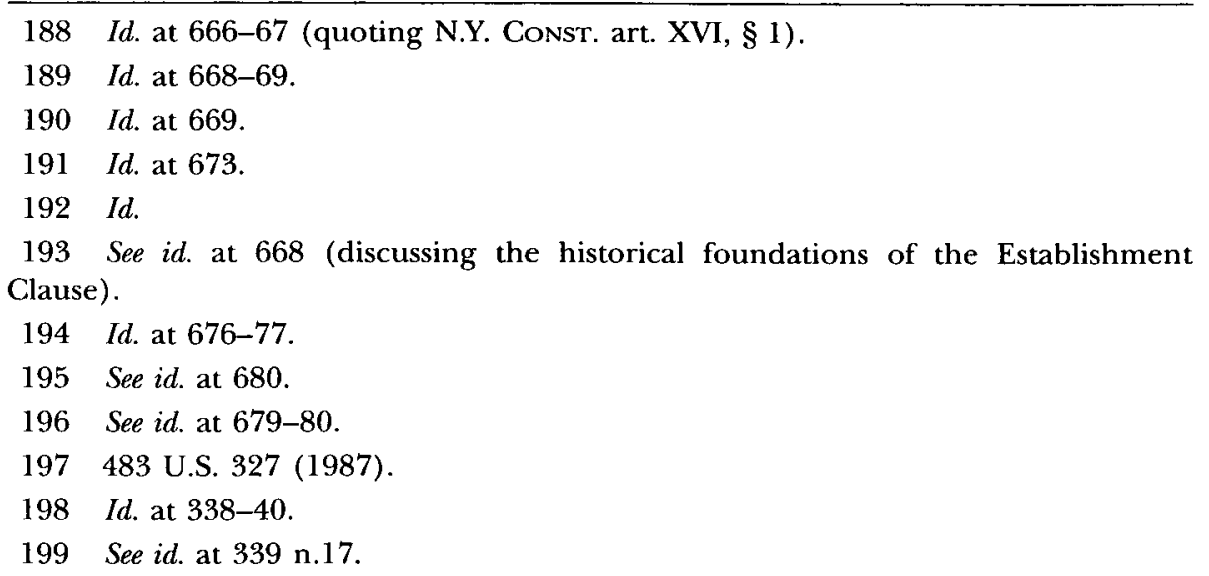


lation to place any free exercise issue beside the point. ${ }^{200}$ The opinion did, however, identify the nondiscrimination law as potentially imposing "a significant burden on a religious organization." 201 That burden would appear to have been countered by a comparably significant establishment concern. The claimed establishment in Walz had been a common, time-tested benefit, enjoyed by educational and charitable institutions as well as churches and extracted almost imperceptibly from the mass of taxpayers. ${ }^{202}$ In contrast, Amos involved specific governmental authorization for churches, and only churches, to discriminate against individual employees. ${ }^{203}$ Justice White, however, found the establishment concern trivial. ${ }^{204}$ Substantively, under the Lemon analysis, ${ }^{205}$ the statute had the "secular purpose" of "alleviat[ing] significant governmental interference with the ability of religious organizations to define and carry out their religious missions." 206

The decisions in Walz and Amos took care to maintain a squarely nonconstitutional basis for the religious accommodations they upheld, ensuring the primacy of legislative authority rather than any free exercise mandate. At the same time, both decisions denied the establishment concerns raised by government decisions to accommodate religion, placing seemingly pivotal decisions about tax benefits and employment discrimination outside the scope of the Establishment Clause. These cases allowed the government's regulatory discretion to overcome the posited nonestablishment interests, just as the unsuccessful mandatory accommodation cases allowed the government's regulatory discretion to overcome the posited free exercise interests. Both sets of cases, like PruneYard and CBS v. FCC in the speech context, ${ }^{207}$ marginalize one First Amendment interest while deferring to regulatory decisions that advance the other.

200 See id. at 334 (employing the Walz analysis of the relationship between accommodation and the Free Exercise Clause).

201 Id. at 336.

202 See Walz v. Tax Comm'n, 397 U.S. 664, 676-77 (1970).

203 See Amos, 483 U.S. at 329-31.

204 See id. at 334-38.

205 See Lemon v. Kurtzman, 403 U.S. 602, 612-13 (1971) (setting forth the Establishment Clause requirements that a challenged government action have a primarily secular purpose, have a principal effect that neither advances nor inhibits religion, and not excessively entangle government with religion).

206 Amos, 483 U.S. at 335.

207 See supra notes 21-28, 68-71 and accompanying text. 


\section{b. Permissive Accommodations Struck Down}

The Court on occasion has struck down permissive accommodations under the Establishment Clause. In Estate of Thomton v. Caldor, Inc. ${ }^{208}$ the Court struck down a Connecticut statute that required all employers to relieve Sabbatarians of work on their Sabbaths. ${ }^{209}$ Writing for the Court, Chief Justice Burger emphasized the strictly religious character of the accommodation and noted that the statute imposed costs both on employers, who had to bear the burden of Sabbatarian employees' limited availability, and on non-Sabbatarian employees, who both missed out on the statute's benefit and had to compensate for its cost. ${ }^{210}$ Accordingly, the Court found that the statute lacked the secular purpose required under the Lemon Establishment Clause test. ${ }^{211}$ Although observance of a Sabbath occupies a central place in many different religious traditions, the majority made no mention of the Free Exercise Clause. Justice O'Connor's concurrence explains the omission: the Court does not consider the Free Exercise Clause applicable to private employers. ${ }^{212}$ However, given the holding in Sherbert that states may not deny benefits to private sector employees fired for observing their Sabbaths, ${ }^{213}$ a decision that turns on the state's power to mandate accommodation of Sabbatarians by private sector employers would seem to implicate the Free Exercise Clause. Rather than assessing the competing First Amendment interests at stake in the Connecticut scheme, the Court simply left the free exercise interest out of its analysis. ${ }^{214}$

\section{U.S. 703 (1985).}

209 See id. at $710-11$.

210 See id. at 708-10.

211 See id. at 709-11.

212 See id. at 712 (O'Connor, J., concurring) (noting the nonapplicability of the Free Exercise Clause mandate to the accommodation of private employees).

213 See Sherbert v. Verner, 374 U.S. 398, 409-10 (1963); supra notes 139-50 and accompanying text.

214 The Court reached a similar result in Larkin v. Grendel's Den, Inc., 459 U.S. 116 (1982), which struck down on Establishment Clause grounds a Massachusetts statute that allowed churches to veto the issuance of liquor licenses for nearby businesses. See id. at 120-27. Although the statute was defended as necessary to "protect" religious institutions, see id. at 120, no Free Exercise Clause argument arose in the case. When the Court in Trans World Airlines, Inc. v. Hardison, 432 U.S. 63 (1977), rejected a Saturday Sabbatarian's argument that the Title VII prohibition on religious discrimination required his employer to relieve him from work on Saturdays, Justice White's majority opinion suggested that such an accommodation would discriminate against nonreligious employees, see id. at 80-81, although the case implicated neither the Free Exercise Clause nor the Establishment Clause. 
The Court achieved the same outcome by different means in Texas Monthly, Inc. v. Bullock. 215 That case, which struck down a state sales tax exemption for religious periodicals, ${ }^{216}$ yielded a splintered majority. Justice Brennan, writing for a three-Justice plurality, emphasized that here, like in Thornton and unlike the superficially similar situation in Walz, only religious believers enjoyed the governmental benefit. ${ }^{217}$ Accordingly, the statute raised serious Establishment Clause concerns. Unlike in Thornton, however, the exemption in Texas Monthly directly alleviated a burden imposed by government. Thus, the case squarely presented a competing free exercise interest. Even so, both the plurality and the principal concurrence found ways to ignore the conflict. Justice Brennan dismissed the interest in taxfree publication as simply too remote from the core of religious belief and activity to animate a mandatory accommodation ${ }^{218}$ or, in the alternative, insufficiently weighty to overcome the government's interest in uniform tax collection. ${ }^{219}$ Justice Blackmun's opinion concurring in the judgment purported to confront the collision between free exercise and nonestablishment interests, and posited the solution of extending the exemption to nonreligious but comparably conscientious publications. ${ }^{220}$ Rather than substantiate and defend that alternative, however, he reverted to the theme of the Court's occasional allowances for expressive access-judicial humility and deference to legislative discretion, which in this case paradoxically required him to strike the statute down. 221

These cases might have provided occasions for considering whether the Free Exercise Clause required, or at least authorized, the challenged accommodations in a manner that might have countered or complicated the Court's Establishment Clause analysis. The Court, however, avoided any such juxtaposition of First Amendment interests. Instead, inverting its reliance in Sherbert and Yoder on the Free Exercise Clause to exempt religious believers from legal obligations while denying the salience of the Establishment Clause, ${ }^{222}$ the Court in Thornton and Texas Monthly invoked the Establishment Clause to restore legal burdens on religious believers while denying the salience of the Free Exercise Clause. Both sets of decisions echo speech cases

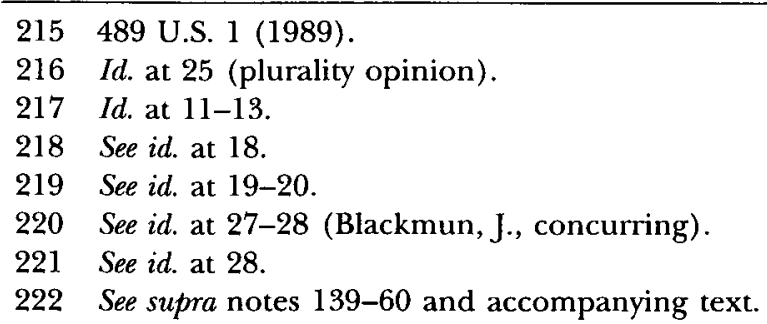


such as Lloyd Corp. and Miami Herald, in which the Court denied the existence of a First Amendment right to expressive access. ${ }^{223}$ As noted above in connection with the successful mandatory accommodation cases, however, the shared textual pedigree of the Free Exercise and Establishment Clauses undermines efforts to deny either competing religious interest. ${ }^{224}$ The Court has decisively addressed this problem by falling back hard on its other patented collision-avoiding technique: deference.

\section{Employment Division v. Smith and Judicial Abstention from Constitutional Questions of Religious Accommodation}

The religious accommodation landscape changed dramatically in 1990 when the Court in Employment Division v. Smith ${ }^{225}$ effectively eliminated mandatory accommodations. ${ }^{226}$ The Smith Court held that the Free Exercise Clause rarely if ever compels the government to provide religious accommodations. ${ }^{227}$ At the same time, the Court encouraged legislators and regulators to accommodate religious interests where they deem accommodation appropriate, without regard to the Establishment Clause. Nullifying the Free Exercise Clause in accommodation disputes while ignoring the significance of the Establishment Clause allowed the Court to accelerate and perfect its move from the earlier cases that rejected mandatory accommodation claims, as well as those that upheld permissive accommodations, to deconstitutionalize conflicts between the Free Exercise Clause and the Establishment Clause.

\section{a. The Smith Decision}

Smith involved a challenge by Native Americans to their denial of unemployment benefits on the ground that they had been fired for cause. The plaintiffs' employer, a drug treatment center, had fired them for using peyote, an illegal drug that their religion considered sacramental. ${ }^{228}$ Justice Scalia's majority opinion. in Smith has grown notorious for its doctrinal contortions in defense of his surprising declaration that "[w]e have never held that an individual's religious beliefs excuse him from compliance with an otherwise valid law

223 See supra notes 14-17, 63-67 and accompanying text.

224 See supra Part I.B.1.a.

225494 U.S. 872 (1990).

226 See id. at 890.

$227 I d$.

228 See id. at 872. 
prohibiting conduct that the State is free to regulate."229 The facts of Smith fell within the one line of mandatory accommodation decisions-the unemployment benefits cases-in which the Court had consistently applied strict scrutiny to require religious accommodations. ${ }^{230}$ Justice Scalia, however, neither followed that line of decisions nor disavowed it. Instead, he distinguished the earlier cases on the grounds that they had not involved violations of criminal law ${ }^{231}$ and had involved "a context that lent itself to individualized governmental assessment of the reasons for the relevant conduct,"232 never explaining why either of those distinctions should make a difference. The opinion distinguished Yoder and earlier decisions on the ground that they arose not just under the Free Exercise Clause but also under some other constitutional provision ${ }^{233}$-thereby spawning the alchemical "hybrid rights" doctrine, which lower courts have spent fifteen futile years trying to render meaningful. ${ }^{234}$ These highly suspect distinctions allowed the Court to use Smith as a vehicle for denying the force of the Free Exercise Clause over the full range of religious accommodation claims.

One might have expected the Court to explain such a sweeping disavowal of free exercise accommodations, at least in part, by reference to the Establishment Clause. Indeed, when he turned from the asserted lack of precedent for mandatory accommodations to affirmative problems with the doctrine, Justice Scalia spoke in terms that resonate vaguely with Establishment Clause concerns about accommodations: the danger of giving religious believers "a private right to ignore generally applicable laws"235 and the fear of "a system in which each conscience is a law unto itself." 236 He hinted at a different sort of Establishment Clause concern in making the questionable assertion that mandatory accommodations required courts to make

\footnotetext{
$229 \quad I d$. at $878-79$.

230 See supra notes 139-54 and accompanying text.

231 See Smith, 494 U.S. at 878-79.

$232 I d$. at 884.

233 See id. at 881-82.

234 See Steven H. Aden \& Lee J. Strang, When a "Rule" Doesn't Rule: The Failure of the Oregon Employment Division v. Smith "Hybrid Rights Exception," 108 PenN ST. L. Rev. $573,587-605$ (2003) (reviewing lower courts' experience in applying hybrid rights doctrine and finding the doctrine ineffectual). The practical failure of the hybrid rights doctrine confirms Michael McConnell's early suggestion that "the notion of 'hybrid' claims was created for the sole purpose of distinguishing Yoder." See Michael W. McConnell, Free Exercise Revisionism and the Smith Decision, 57 U. CHI. L. Rev. 1109, $1121(1990)$.

235 Smith, 494 U.S. at 886.

236 Id. at 890.
} 
unsavory judgments about the "centrality" of particular religious practices. ${ }^{237}$ In the end, however, the Smith Court oriented religious accommodation doctrine in the direction most fraught with establishment dangers. Declaring that "[v]alues that are protected against government interference through enshrinement in the Bill of Rights are not thereby banished from the political process,"238 Justice Scalia invited federal and state officials to dole out whatever religious exemptions might strike their political fancies, notwithstanding that "leaving accommodation to the political process will place at a relative disadvantage those religious practices that are not widely engaged in." 239

\section{b. Permissive Accommodation After Smith}

Smith has had the predictable effects of clearing most religious accommodation cases from the Court's docket and ushering in a bonanza of discretionary religious accommodations. ${ }^{240}$ Congress responded to Smith by enacting the Religious Freedom Restoration Act of 1993 (RFRA), ${ }^{241}$ which sought to reimpose the Sherbert strict scrutiny standard for all mandatory accommodation claims. Although the Court loudly struck down RFRA on federalism grounds in City of Boerne v. Flores, ${ }^{242}$ it recently made clear in Gonzales v. O Centro Espirita Beneficente Uniao do Vegetal ${ }^{243}$ what Boerne implied by omission-that RFRA remains effective for claims against the federal government. ${ }^{244}$ Neither Boerne nor $O$ Centro considered any implications of the Establishment Clause for RFRA's broad mandate of discretionary accommodations. ${ }^{245}$

Although Smith would appear to have cleared the accommodation field for more focused consideration of Establishment Clause lim-

\footnotetext{
237 See id. at $886-87$.

238 Id. at 890.

239 Id

240 See Diana B. Henriques, Religion Trumps Regulation as Legal Exemptions Grow, N.Y. Times, Oct. 8, 2006, $\$ 1$, at A1.

241 Pub. L. No. 103-141, 107 Stat. 1488 (codified as amended at 42 U.S.C. $\S \S 2000 \mathrm{bb}$ to $2000 \mathrm{bb}-4(2000)$ ), invalidated in part by City of Boerne v. Flores, 521 U.S. 507 (1997).

242521 U.S. 507,536 (1997).

243546 U.S. 418 (2006).

$244 I d$. at 424. For a discussion of RFRA's constitutionality as applied to federal law after Boerne, see Magarian, supra note 136, at 1917-61.

245 Justice Stevens, concurring in Boerne, would have struck down RFRA on its face as a violation of the Establishment Clause. See Boerne, 521 U.S. at 536-37 (Stevens, J., concurring). Justice Stevens joined the unanimous $O$ Centro opinion without writing separately. $O$ Centro, 546 U.S. at 422.
} 
its on discretionary accommodations, the Court has taken up few such cases over the past fifteen years. In Cutter $v$. Wilkinson, ${ }^{246}$ the Justices unanimously rejected an ambitious Establishment Clause argument that the Religious Land Use and Institutionalized Persons Act of 2000 (RLUIPA), ${ }^{247}$ a micro-RFRA that requires strict scrutiny of religious burdens on federal prisoners, was invalid on its face. ${ }^{248}$ Echoing Amos, Justice Ginsburg's opinion found that the Act merely "alleviates exceptional government-created burdens on private religious exercise." ${ }^{49}$ The only post-Smith case in which the Court has struck down a discretionary accommodation is Board of Education of Kiryas Joel Village School District $v$. Grumet, ${ }^{250}$ which rejected New York's creation of a special school district for members of the Satmar Hasidim. ${ }^{251}$ Justice Souter's majority opinion found that creating the special district extended beyond noninterference with religion to "single[ ] out a particular religious sect for special treatment," 252 thereby violating the principle that "neutrality as among religions must be honored." 253 Notwithstanding Justice Scalia's vigorous dissent in Kiryas Joel, ${ }^{254}$ both that case and Cutter produced unremarkable outcomes. The Court generally disdains the sort of facial challenge brought in Cutter. ${ }^{255}$ Kiryas Joel represents the Court's clearest acknowledgement that favoritism toward even a minority religion can violate the Establishment Clause, but the unusual accommodation in that case implicated a core function of government more directly than the Sabbath relief of Thornton or the tax exemption of Texas Monthly.

The only other recent decision in which the Court credited nonestablishment interests in the context of a free exercise claim was Locke v. Davey. ${ }^{256}$ In that case, a college student majoring in pastoral ministry argued that the State of Washington's refusal to make devo-

\footnotetext{
246544 U.S. 709 (2005).

24742 U.S.C. $\$ \S 2000 \mathrm{cc}$ to $2000 \mathrm{cc}-5$ (2000).

248 See Cutter, 544 U.S. at 725-26.

$249 I d$. at 720; see supra notes 197-206 and accompanying text. As in $O$ Centro, Justice Stevens wrote no separate opinion in Cutter, declining another opportunity to press the Establishment Clause concern he voiced in his Boeme concurrence. See Cutter, 544 U.S. at 711.

250512 U.S. 687 (1994).

251 See id. at 706-09.

$252 I d$. at 706.

253 Id. at 707.

254 See id. at 732 (Scalia, J., dissenting).

255 See United States v. Salerno, 481 U.S. 739, 745 (1987) (holding that, for a facial challenge to succeed, "the challenger must establish that no set of circumstances exists under which the [challenged regulation] would be valid").

256540 U.S. 712 (2004).
} 
tional theology students eligible for a state scholarship program constituted discrimination against religion in violation of the Free Exercise Clause. ${ }^{257}$ Writing for the Court, Chief Justice Rehnquist found that the student had not made the demanding showing required to establish free exercise discrimination. ${ }^{258}$ The Chief Justice split the Establishment Clause baby in an odd way. Veering into dicta, the opinion declares that the Establishment Clause would not have barred extending the scholarship funds to devotional study. ${ }^{259}$ Then, invoking the "play in the joints" formulation of Walz, ${ }^{260}$ the Court credits Washington's explanation that it sought not to discriminate against religion but only to avoid violating the nonestablishment requirement of the state constitution, which imposes a stronger bar than the Federal Establishment Clause against funding religion. ${ }^{261}$ In vindicating Washington's position, the Court comes close to endorsing in principle the nonestablishment imperative to withhold state funds from ministerial studies. ${ }^{262}$ Despite its nuanced rhetoric, however, Locke reduces to a predictable extension of Smith deference, rebuffing an effort to extend the zone of religious discrimination in which the Court gives meaningful effect to the Free Exercise Clause while reiterating the Court's narrow view of the Establishment Clause. ${ }^{263}$

Smith dramatically weakens the force of both the Free Exercise Clause and the Establishment Clause in religious accommodation cases. The Smith Court openly diminished the Free Exercise Clause to a prohibition on deliberate discrimination against religion. Although the Court barely mentioned the Establishment Clause and offered no new guidance for adjudicating permissive accommodation disputes, its enthusiastic channeling of accommodation claims into the political process eviscerated the Establishment Clause as a check on permissive accommodations. Smith averts the need to justify denying one or

257 See id. at 717-18.

258 See id. at 725.

259 See id. at 719.

260 See id. at 718 (citing Walz v. Tax Comm'n, 397 U.S. 664, 669 (1970)). For a more complete discussion of Walz, see supra notes 187-96 and accompanying text.

261 See Locke, 540 U.S. at 722-23.

262 See id. at 722 ("[W] can think of few areas in which a State's antiestablishment interests come more into play.").

263 Justice Scalia, dissenting in Locke, provides a rare critique of the Court's "play in the joints" approach to conflicts between the two religion clauses, calling it "not so much a legal principle as a refusal to apply any principle when faced with competing constitutional directives." Id. at 728 (Scalia, J., dissenting). Justice Scalia, however, views the two clauses as perfectly coordinated to "demand neutrality," not as coming into any sort of conflict. Id. 
another First Amendment interest in particular religious accommodation scenarios by categorically denying the First Amendment's salience for nearly all accommodation disputes. This strategy obviates any danger of a First Amendment collision involving the Free Exercise Clause and strongly decreases the likelihood that establishment concerns will pull the Court into substantive constitutional analysis of religious accommodations.

c. The Free Speech Clause vs. the Establishment Clause: Religious Speakers' Claims on Public Resources

A distinct line of decisions involves a collision of First Amendment interests that crosses the median between expressive and religious interests. In most of these cases, public educational institutions seek to deny otherwise generally available expressive resources to religious groups or speakers, based on the government's asserted interest in avoiding violations of the Establishment Clause. Widmar $v$. Vincent ${ }^{264}$ involved a university's denial of meeting space to a religious student group. ${ }^{265}$ In Lamb's Chapel v. Center Moriches Union Free School District, ${ }^{266}$ a school district refused to let a church group use school property after hours for a film showing. ${ }^{267}$ Rosenberger $v$. Rector $\mathcal{E} v$ Visitors of University of Virginia ${ }^{268}$ dealt with a university's withholding of student activity funds from a religious publication. ${ }^{269}$ In Good News Club v. Milford Central School, ${ }^{270}$ a school district once again denied access to school property after hours for a religious function, this time for meetings of a religious children's group. ${ }^{271}$ In each case, the Court ruled in favor of the religious group. ${ }^{272}$ The cases have played out over two decades, and the majority opinions employ somewhat varied reasoning, but the decisions make a consistent set of core points: school property made available for third parties' use is a limited public forum; ${ }^{273}$ denying access specifically for religious speakers

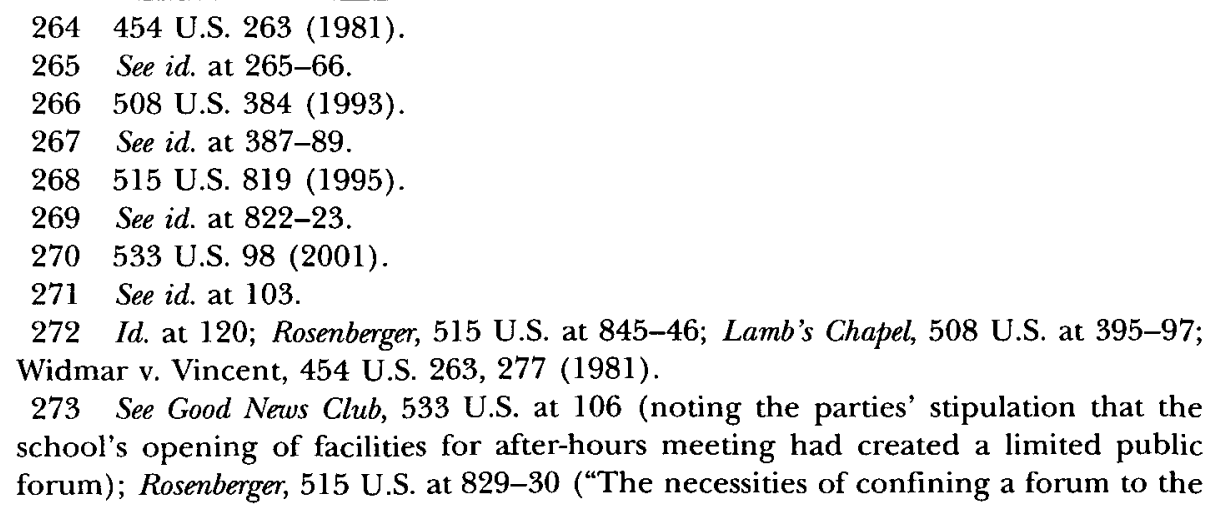


amounts to an impermissible viewpoint-based exclusion; ${ }^{274}$ and government in these circumstances has no valid concern that opening the forum to religious expression would violate the Establishment Clause. ${ }^{275}$ The Court followed identical reasoning to a similar result in Capitol Square Review $\mathcal{E} \mathcal{F}^{2}$ Advisory Board v. Pinette, ${ }^{276}$ which found that the Free Speech Clause protected, and the Establishment Clause did not restrict, the Ku Klux Klan's display of an unattended cross on state capitol grounds open to a variety of expression. ${ }^{277}$

The government's role in these religious speech disputes distinguishes them from expressive access cases. The public-private distinction has led the Court in public forum cases to find a limited First Amendment access right to public property, even as it has rejected the idea of an access right to private property. ${ }^{278}$ The public-private distinction also limits the government to pleading its regulatory prerogatives, as opposed to constitutional rights, in countering the First Amendment right of expressive access to public forums. What distinguishes these religious speech disputes from ordinary public forum cases is that the government dons a constitutional cloak by invoking its responsibility to respect the Establishment Clause. Thus, these

limited and legitimate purposes for which it was created may justify the State in reserving it for certain groups or for the discussion of certain topics."); Lamb's Chapel, 508 U.S. at 391-93 (suggesting that school facilities might have been a public forum but assuming arguendo that they were a nonpublic forum); Widmar, 454 U.S. at 268 n.5 ("A university's mission is education, and decisions of this Court have never denied a university's authority to impose reasonable regulations compatible with that mission upon the use of its campus and facilities.").

274 See Good News Club, 533 U.S. at 107-10; Rosenberger, 515 U.S. at 830-32; Lamb's Chapel, 508 U.S. at 393-94; Widmar, 454 U.S. at 269 (stating that the University "discriminated against student groups and speakers based on their desire to use a generally open forum to engage in religious worship and discussion").

275 See Good News Club, 533 U.S. at 113-14 (holding that allowing a religious group to meet on school property would present no danger of endorsement of religion); Rosenberger, 515 U.S. at $839-40$ (holding that inclusion of a religious beneficiary in a generally available funding scheme does not violate the Establishment Clause); Lamb's Chapel, 508 U.S. at 395-96 (concluding that University's creation of a public forum could not violate the Establishment Clause); Widmar, 454 U.S. at 272-73 (" $[\mathrm{A}] \mathrm{n}$ open forum in a public university does not confer any imprimatur of state approval on religious sects or practices.").

$276 \quad 515$ U.S. 753 (1995).

277 See id. at 770. The majority portion of Justice Scalia's opinion in Capitol Square followed Widmar and Lamb's Chapel without much embellishment. See id. at 757-63. The remainder of the opinion, which garnered only plurality support, sought to discredit posited distinctions between the educational institution cases and the distinctive facts of Capitol Square. See id. at 763-70 (plurality opinion).

278 See supra note 2 and accompanying text (distinguishing expressive access and public forum disputes). 
cases present a distinctive instance of colliding First Amendment interests. The religious speaker plaintiffs literally seek expressive access, but the public forum doctrine grants their interests a degree of constitutional legitimacy that expressive access claims against private defendants, as well as post-Smith free exercise accommodation claims, lack. The government defendants, meanwhile, invoke the Establishment Clause to vindicate the people's First Amendment interest in nonestablishment.

The manifest necessity in the religious speech cases of analyzing the competing free speech and nonestablishment claims suggests that here, at last, the Justices must squarely confront a collision of First Amendment interests. The decisions' reasoning, however, finds a path to denial. The notoriously elastic public forum doctrine allows the Court to treat these particular speakers' interests not merely as constitutionally legitimate but rather as something akin to the robust interest in expressive autonomy. The decisions portray the plaintiffs as seeking not special treatment but merely equal treatment, ${ }^{279}$ and they portray the government not merely as foreclosing opportunities but as censoring ideas. ${ }^{280}$ On the other hand, the decisions employ the anemic Establishment Clause rhetoric of successful religious accommodation cases such as Sherbert and Walz, ubiquitous after the Smith Court's license for discretionary accommodations. Especially in the more recent religious speech decisions, the majority emphasizes that the Free Speech Clause compels the government to give religious entities whatever it gives otherwise comparable secular entities, characterizing governmental nonsupport of religious speech based on Establishment Clause concerns as a "heckler's veto."281 The principle that animates a more forceful account of the Establishment Clausethat governmental support of religion creates constitutionally cognizable hazards-has faded out of the picture entirely.

The Court in the religious speech cases does not substantively assess the relative merits of the asserted free speech and nonestablishment interests. Rather, it does exactly what it did in failed expressive access cases such as Lloyd Comp. and Miami Herald, the successful

279 See, e.g., Widmar, 454 U.S. at 273 ("The University has opened its facilities for use by student groups, and the question is whether it can now exclude groups because of the content of their speech.").

280 See, e.g., Lamb's Chapel, 508 U.S. at 394 (stating that a school district denied access for religious film showings "solely because the series dealt with the subject from a religious standpoint").

281 Good News Club v. Milford Cent. Sch., 533 U.S. 98, 119 (2001) (stating that " [w]e decline to employ Establishment Clause jurisprudence using a modified heckler's veto"). 
mandatory accommodation cases Sherbert and Yoder, and the successful challenges to permissive accommodations in Thornton and Texas Monthly-wholly embracing one competing First Amendment interest while categorically denying the existence or salience of another. The religious speech decisions do not conclude that expressive autonomy interests, in the circumstances, outweigh nonestablishment interests. Rather, they declare that government officials have blatantly violated expressive freedom and senselessly invoked the Establishment Clause where it has no proper application. These decisions reaffirm the Court's general solicitude for expressive autonomy and general lack of anxiety that government establishes religion by assisting religious entities. What they do not do, any more than the expressive access or religious accommodation decisions, is tell us anything about how the Court would decide a case in which it acknowledged the presence of two colliding First Amendment interests.

\section{Resolving First Amendment Collisions Under Participiation-Enhancing Review}

In the three seemingly disparate contexts of expressive access, religious accommodation, and religious speech decisions, the Supreme Court resorts to some combination of two techniquesdenial of one of the competing interests and deference to elected decisionmakers-in order to avoid substantive resolution of First Amendment collisions. The striking consistency in the Court's approach indicates that these three categories of First Amendment collisions share some important, fundamental attributes. Every First Amendment dispute, whether focused on speech, religion, or both, involves - at least in theory-fundamental issues of individual conscience. The importance of those conscientious issues for shaping individuals' participation in society means that every First Amendment dispute also affects the process of collective self-government that defines our democratic system. Recognizing the stakes of First Amendment disputes for democratic government helps to explain the Court's use of denial and deference to avoid substantive resolution of First Amendment collisions. Where interests charged with democratic significance come into direct conflict, assertive judicial review may appear to encroach on the domain of democratic policymaking.

The democratic salience of First Amendment collisions, however, underscores the problem with the Court's approach. The First Amendment contributes substantially to the constitutional structure of our democracy, and any collision between structural elements creates the most pressing need for authoritative constitutional resolution. 
Thus, the many important cases in which First Amendment interests collide should compel the Court to extricate itself from the tangled web of denial and deference and to embrace a mode of adjudication that allows the Justices to construe and enforce the First Amendment's commands. This Part diagnoses the failings of the Court's approach and proposes an alternative way to adjudicate First Amendment collisions, based on a commitment to advancing participatory democracy. Proceeding from John Hart Ely's elaboration of representation-reinforcing review-the most thorough justification for assertive judicial enforcement of constitutional rights as an essential component of our democratic system-I call the proposed alternative participation-enhancing review.

The first half of this Part critically analyzes why the Court has consistently met First Amendment collisions with the techniques of denial and deference that Part I describes. The dominant theme in the expressive access, religious accommodation, and religious speech decisions alike is the need for the government to treat ideas and speakers, and faiths and believers, in a neutral manner. By using denial and deference to enforce government neutrality, the Court ultimately seeks to maintain neutrality in its own decisions. Denying the existence of First Amendment collisions when possible, and deferring to elected decisionmakers when necessary, avoids visible resort to the substantive values necessary for choosing one First Amendment interest over another and thus precludes usurping democratically elected officials' policymaking authority. The Court's reliance on denial and deference, however, conceals normatively charged baselines: in the speech cases, a formalistic conception of the public-private distinction and a rarefied ideal of autonomy; in the religion cases, a disregard for the interests of minority religious believers and a strong tolerance for government favoritism toward religious interests. The Court's approach to these cases creates a false impression of neutrality in the name of democratic government, but the Court disserves our democratic system by failing to confront and apply the First Amendment principles that make that system work.

A better approach to these important cases would forthrightly acknowledge the presence of First Amendment collisions and assess them under an analytic method firmly grounded in democratic principles. The second half of this Part contends that the Court can choose between colliding First Amendment values, and justify its choices, by relying on a substantive conception of democratic participation. Beginning from the familiar theory of representation-reinforcing review, I explain how a focus on the informative and inclusive qualities of democratic participation provides a basis for the Court to make 
substantive constitutional judgments about which of two colliding First Amendment interests should prevail in any given case. The participation-enhancing review that I propose would lead the Court to consider whether granting a putative speaker access to expressive property would enhance or diminish the quality of public debate, and whether exempting a religious believer from a legal obligation would advance or retard the vitality of democratic discourse. In practice, these inquiries would favor dissenting and minority perspectives, whatever their substantive viewpoints, in speech and religion. If the Court justified its choices between First Amendment interests in terms of facilitating and advancing people's capacity to participate meaningfully in democratic processes, most people, most of the time, would consider the Court's grounds for decision democratically legitimate, and the Court would satisfy its obligation to implement the First Amendment in cases that raise profound constitutional issues about speech and religion.

\section{A. Neutrality as the Supreme Court's Conceptual Basis for Refusing to Confront First Amendment Conflicts}

In every sort of speech and religion dispute that brings First Amendment interests into collision, the Supreme Court forestalls substantive resolution by purporting to make the less momentous inquiry of whether the relevant governmental decisionmaker has behaved neutrally toward ideas and speakers, or between faiths and believers. Thus, for example, the gay-lesbian would-be parade marchers in $\mathrm{Hur}$ ley v. Irish-American Gay, Lesbian $\mathcal{E}^{2}$ Bisexual Group of Boston, Inc. ${ }^{282}$ suffered no violation of expressive freedom because the government did not restrict the content of their speech;283 the Native American church members in Employment Division $v$. Smith ${ }^{284}$ suffered no violation of free exercise because the government treated them the same as everyone else; ${ }^{285}$ the Christian student group in Rosenberger $v$. Rector $\mathcal{E}^{2}$ Visitors of University of Virginia ${ }^{286}$ did suffer a violation of expressive freedom because the state university treated the group differently than it treated similar organizations. ${ }^{287}$ The surface of virtually every First Amendment collision case strongly conveys the message that the

282515 U.S. 557 (1995); see supra notes 37-47 and accompanying text.

283 See Hurley, 515 U.S. at 580-81.

284494 U.S. 872 (1990); see supra notes 225-39 and accompanying text.

285 See Smith, 494 U.S. at 890.

286515 U.S. 819 (1995); see supra note 268 and accompanying text.

287 See Rosenberger, 515 U.S. at 845-46. 
Court need only determine whether or not the government has treated opposing parties and interests neutrally.

Neutrality, of course, is a prominent trope in both free speech and religious freedom doctrine. The central question in the Court's free speech analysis is whether a challenged regulation is neutral as to the content of speech. ${ }^{288}$ Neutrality is one of two ever-contending models-separation is its opposite number-for the Court's Establishment Clause jurisprudence, ${ }^{289}$ while Free Exercise Clause doctrine has come to focus almost completely on neutral treatment of religious beliefs and believers. ${ }^{290}$ Numerous commentators have emphasized how the Court's focus on neutrality has hampered its First Amendment decisions on free speech ${ }^{291}$ and religion. ${ }^{292}$ Even so, an emphasis on neutrality seems intuitively desirable in cases of colliding First

288 See, e.g., Police Dep't v. Mosley, 408 U.S. 92, 99 (1972) (holding that regulating speech "in terms of subject matter . . is never permitted").

289 Compare, e.g., Everson v. Bd. of Educ., 330 U.S. 1, 18 (1947) (holding that the Establishment Clause "requires the state to be a neutral in its relations with groups of religious believers and non-believers"), with Engel v. Vitale, 370 U.S. 421, 431 (1962) (holding that the "first and most immediate purpose [of the Establishment Clause] rested on the belief that a union of government and religion tends to destroy government and to degrade religion"). See generally Douglas Laycock, Formal, Substantive, and Disaggregated Neutrality Toward Religion, 39 DePAul L. Rev. 993 (1990) (clarifying the meaning of "neutrality" as it relates to religious liberty).

290 See, e.g., Church of the Lukumi Babalu Aye, Inc. v. City of Hialeah, 508 U.S. 520,547 (1993) (striking down a local animal cruelty ordinance whose prohibitions specifically targeted a religious group).

291 Recent critiques of neutrality as a central feature of free speech doctrine include Erwin Chemerinsky, Content Neutrality as a Central Problem of Freedom of Speech: Problems in the Supreme Court's Application, 74 S. Cal. L. Rev. 49, 53-64 (2000) (criticizing several applications of the content neutrality principle); John Fee, Speech Discrimination, 85 B.U. L. REv. 1103, 1169-70 (2005) (arguing that the Court should subordinate the content neutrality principle to the goal of promoting public debate); Steven J. Heyman, Spheres of Autonomy: Reforming the Content Neutrality Doctrine in First Amendment Jurisprudence, 10 WM. \& MARY BILL RTS. J. 647, 705-06 (2002) (arguing that the content neutrality principle should not bar limitations on speech that violates the rights of others).

292 Recent critiques of neutrality as a central feature of Establishment Clause doctrine include Steven K. Green, Of (Un)Equal Jurisprudential Pedigree: Rectifying the Imbalance Between Neutrality and Separationism, 43 B.C. L. REv. 1111, 1136-37 (2002) (arguing that the Court should emphasize separation and limit neutrality to an adjunct role); Frank S. Ravitch, A Funny Thing Happened on the Way to Neutrality: Broad Principles, Formalism, and the Establishment Clause, 38 GA. L. Rev. 489, 492 (2004) (criticizing the Court's increasing reliance on neutrality in Establishment Clause cases and claiming that neutrality does not exist); Keith Werhan, Navigating the New Neutrality: School Vouchers, the Pledge, and the Limits of a Purposive Establishment Clause, 41 BRANDEIS L.J. 603, 603-04 (2003) (criticizing the Court's oscillation between "substantive" and "purposive" neutrality). 
Amendment interests, because those cases present the Court with a conflict between constitutional principles as to which any decisive resolution might appear undesirably biased.

The Court in First Amendment collision cases therefore seeks to ensure governmental neutrality by employing techniques that it holds out as neutral principles of decision: denial and deference. ${ }^{293}$ In each case of a First Amendment collision, however, reliance on those techniques submerges one or both of two deeply rooted First Amendment interests-autonomy or access, free exercise or nonestablishment. As my discussion will demonstrate, the Court's approach fails on two levels. The Justices' use of denial and deference undermines their commitment to neutrality in resolving First Amendment collisions, and that commitment to neutrality betrays their responsibility to interpret and enforce the First Amendment.

\section{Neutrality in Expressive Access Cases}

The Court's primary approach to collisions between expressive autonomy and expressive access interests is to deny that the First Amendment provides any basis for expressive access claims. The Court builds this denial on two primary rhetorical supports: a rigid account of the public-private distinction and a singular focus on maintaining expressive autonomy to the exclusion of any other expressive interest. The Court places these two elements squarely in the foreground of decisions that deny the existence of expressive access interests. What the two elements share is their strong resonance with a narrative of neutrality - the idea that a principled court is simply instructing the government to treat different speakers and viewpoints in an unbiased manner. The Court presents both its account of the public-private distinction and its fixation on expressive autonomy as if they are objectively necessary ingredients of a neutral First Amendment analysis. In fact, both positions reflect strong and consequential normative choices. Likewise, where legislative provisions for expressive access cause the Court to retreat into deference, its seemingly neutral respect for legislative discretion serves to avert closer scrutiny of its denial of a constitutional access interest.

The Court prominently invokes the distinction between private constitutional rights and public constitutional obligations as a basis for denying that the First Amendment supports any interest in access

293 The classic argument for the value of neutral decisional principles is Herbert Wechsler, Toward Neutral Principles of Constitutional Law, 73 Harv. L. Rev. 1 (1959). See also Robert H. Bork, THe Tempting of AMErica 143-53 (1990) (advocating judicial reliance on neutral principles). 
to the means of expression. In CBS, Inc. $v$. Democratic National Commit$t e e,{ }^{294}$ a plurality of the Court dismissed political activists' demand to buy advertising on national broadcast networks as an improper effort to impose constitutional constraints on private editorial judgment. ${ }^{295}$ The Court in Hurley treated a gay organization's plea for access to a prominent community event as an assertion of legislative antidiscrimination policy against the private parade organizers' choice of which perspectives to present. ${ }^{296}$ Invoking the public-private distinction to delegitimize expressive access claims allows the Court, on the surface, to avoid making substantive judgments about the relative values of competing speakers and ideas. Public authorities' obligation to respect private speakers' prerogatives makes for a comfortingly linear and value-neutral narrative. That narrative, however, ignores the government's essential role in creating and sustaining private prerogatives, ${ }^{297}$ and it stacks the rhetorical deck by holding out a formal distinction in status as a proxy for actual differences in power. The incongruous result is a legal regime that falls over itself to protect an enormous, publicly licensed broadcasting corporation and the publicly sanctioned organizers of a dominant ethnic group's most renowned urban spectacle from political dissidents and sexual pariahs. The Court's rigid application of the public-private distinction to expressive access disputes goes far beyond the laudable aim of protecting individuals' expressive integrity to shield powerful institutions' expressive resources against distributional challenges. The substantive effect is to favor established wisdom over unruly dissent. ${ }^{298}$

The Court's other basis for denying a First Amendment interest in expressive access is its overriding emphasis on autonomy as a free speech value. In Miami Herald Publishing Co. $v$. Tormillo, ${ }^{299}$ the Court treated a media corporation's editorial discretion as an especially potent instance of expressive autonomy and made clear that the autonomy interest left no room in the First Amendment for access

\footnotetext{
294412 U.S. 94 (1973); see supra notes 57-62 and accompanying text.

295 See CBS v. DNC, 412 U.S. at 132.

296 See Hurley v. Irish-Am. Gay, Lesbian \& Bisexual Group of Boston, 515 U.S. 557, 572-75 (1995); supra notes 37-47 and accompanying text.

297 See, e.g., SunSTEIN, supra note 3, at 36-37 (explaining the essential role of law in distributing opportunities for expression).

298 I develop this critique of the public-private distinction more thoroughly, and apply it in the particular context of nongovernmental censorship of wartime dissent, in Gregory P. Magarian, The First Amendment, the Public-Private Distinction, and Nongovernmental Suppression of Wartime Political Debate, 73 GEo. WASH. L. REv. 101, 135-51 (2004).

299418 U.S. 241 (1974); see supra notes 63-67 and accompanying text.
} 
interests. ${ }^{300}$ In Pacific Gas $\mathcal{E}^{2}$ Electric Co. v. Public Utilities Commission, ${ }^{301}$ the Court treated the public's interest in information about utility issues as a mere outgrowth of the utility's interest in controlling the content of its billing envelopes, dismissing political dissenters' efforts to add information to the envelopes as an attempt to impose a species of censorship. ${ }^{302}$ Likewise, Buckley $v$. Valeo ${ }^{303}$ rejected controls on political expenditures as improper constraints on the autonomy of well-financed speakers. ${ }^{304}$ The Court's fixation on autonomy, like its reliance on the public-private distinction, creates an image of governmental and judicial neutrality. What, these decisions ask, could be more neutral than letting speakers speak, and what could be more improperly biased than forcing them to bear the din of opposing speakers? In the Court's portrayal, expressive autonomy facilitates valuable expression by those who have earned the right to participate in public debate, while constitutional claims for access seek to poach legitimate speakers' expressive autonomy. Once again, however, this picture of neutrality disguises a more complicated, normatively charged choice. ${ }^{305}$ Single-minded emphasis on autonomy favors the expressive haves over the have-nots. ${ }^{306}$ No one who already possesses expressive resources needs to claim an interest in access to those resources, and no one who lacks expressive resources has any basis for claiming an interest in expressive autonomy. Even more problematic for First Amendment doctrine, a bias toward established speakers tends to yield a bias toward established viewpoints.

In relying on the public-private distinction and reifying the value of expressive autonomy, the Justices might be acting upon substantively defensible judgments. Perhaps they believe a formalist version of the public-private distinction will usually assign rights and impose

300 See Miami Herald, 418 U.S. at 258. The Court in a subsequent case went so far as to invoke the primacy of editorial autonomy in spite of the public-private distinction, using a particularly narrow conception of the public forum doctrine to protect a public broadcaster from the obligation to articulate objective standards for excluding a minor-party political candidate from a televised electoral debate. See Ark. Educ. Television Comm'n v. Forbes, 523 U.S. 666, 683 (1998).

301475 U.S. 1 (1986); see supra notes $29-36$ and accompanying text.

302 See Pacific Gas, 475 U.S. at 13-15, 20-21.

303424 U.S. 1 (1976) (per curiam); see supra notes 110-20 and accompanying text. 304 See Buckley, 424 U.S. at 52-53, 143.

305 The Court itself has at times declared that expressive freedom means more than just expressive autonomy. See, e.g., N.Y. Times Co. v. Sullivan, 376 U.S. 254, 270 (1964) (emphasizing "a profound national commitment to the principle that debate on public issues should be uninhibited, robust, and wide-open").

306 See, e.g., OWen M. Fiss, The Irony of Free SPeech 9-18 (1996) (discussing the tension between the First Amendment values of liberty and equality). 
obligations in a manner that comports with the best understanding of constitutional expressive freedom. ${ }^{307}$ Perhaps their emphasis on expressive autonomy to the total exclusion of expressive access reflects a theory of rights that takes access interests into account and finds them philosophically wanting. ${ }^{308}$ Such bases for the Court's positions would at least enable a normative justification for denying the existence of a First Amendment interest in expressive access. Unfortunately, the Court has made no substantial effort to defend its conception of the public-private distinction or its exclusive embrace of expressive autonomy, on those or any other grounds. Instead, the Court's decisions simply invoke these normative preferences as if they were organic, unassailable components of a substantively neutral free speech doctrine. That sleight of hand obscures the access decisions' inherent slant toward status quo distributions of expressive opportunities. As such, the Court's reliance on the public-private distinction and preoccupation with expressive autonomy foment doctrinal confusion and even create the capacity for engineering preferred outcomes under cover of purportedly neutral principles.

Discretionary government regulations to expand expressive access, as seen in such cases as PruneYard Shopping Center v. Robins ${ }^{309}$ and CBS, Inc. v. FCC, ${ }^{310}$ put the Court in a difficult position. If the Justices asserted expressive autonomy as a constitutional value to trump regulatory access initiatives, they would have to provide some substantive resolution of the conflict between the competing interests. They could not simply ignore the expressive access interest, because the government's regulatory initiative imbues the interest with salience. Conversely, the Court's denial of First Amendment expressive access interests precludes it from validating the government's action on constitutional grounds. The path of least resistance, charted in the Court's decisions, is to defer the determination whether and to what extent access interests may compromise autonomy interests to legisla-

307 Exemplars of this sort of argument include Julian N. Eule \& Jonathan D. Varat, Transporting First Amendment Norms to the Private Sector: With Every Wish There Comes a Curse, 45 UCLA L. Rev. 1537, 1554-64. (1998); Robert Post, Meiklejohn's Mistake: Individual Autonomy and the Reform of Public Discourse, 64 U. CoLo. L. REv. 1109, 1125-28 (1993); Kathleen M. Sullivan, Resurrecting Free Speech, 63 Fordham L. Rev. 971, 979-82 (1995). For a critical response, see Magarian, supra note 298, at 135-50.

308 Exemplars of this sort of argument include MARTIN H. REDISH, MONEY TALKS 147-95 (2001); Robert Post, Equality and Autonomy in First Amendment Jurisprudence, 95 MıCH. L. REV. 1517, 1534-38 (1997); Kathleen M. Sullivan, Discrimination, Distribution and Free Speech, 37 ArIz. L. Rev. 439, 446-51 (1995). For a critical response, see Magarian, supra note 5, at 1393-99.

309447 U.S. 74 (1980); see supra notes 21-28 and accompanying text.

310453 U.S. 367 (1981); see supra notes $68-71$ and accompanying text. 
tive discretion, effectively pretending the constitutional problem does not exist. The Court attempts to justify its deference to legislative access initiatives through narrow, context-specific diminutions of expressive autonomy interests-for example, the interest in excluding certain speakers from shopping areas open to the public or the interest in discriminating against political candidates in the sale of advertising. Unfortunately, the Court elsewhere recognizes precisely those interests as exemplars of its ordinary, robust account of expressive autonomy. ${ }^{311}$ Thus, the Court's deference, designed to reinforce an image of principled neutrality, underscores the normative bias inherent in the Court's denial of expressive access interests.

\section{Neutrality in Religious Accommodation Cases}

In the religious accommodation context, as in the expressive access context, the Supreme Court defines the government's obligation in terms of neutrality. The Court employs neutrality rhetoric much more directly in the accommodation cases, routinely claiming that its outcomes preserve neutral treatment of beliefs and believers. ${ }^{312}$ The path to the Court's own purportedly neutral approach toward accommodation claims has taken more complicated turns than in the speech setting. Earlier religious accommodation decisions variously invoked the Free Exercise Clause and the Establishment Clause as servants of neutrality, always denying or ignoring the opposite, competing First Amendment interest. Then, in a dual progression that culminated in Employment Division $v$. Smith, ${ }^{313}$ the Court settled on deference to elected officials as its mechanism for project-

311 Compare PruneYard, 447 U.S. at 88 (1980) (holding that state constitutional provisions, which permit individuals to exercise free speech on the property of a privately owned shopping center to which the public is invited, did not violate the shopping center owner's First Amendment rights), with Lloyd Corp. v. Tanner, 407 U.S. 551, 567 (1972) ("It would be an unwarranted infringement of property rights to require [expressive property owners] to yield to the exercise of First Amendment rights under circumstances where adequate alternative avenues of communication exist."); compare also CBS, Inc. v. FCC, 453 U.S. at 396-97 (1981) (holding that the Communications Act of 1934, in authorizing the FCC to revoke broadcasters' licenses for willful or repeated failure to allow legally qualified candidates for federal elective office a special right of access to broadcasting, on an individual basis, is not a violation of broadcasters' First Amendment rights), with CBS, Inc. v. Democratic Nat'l Comm., 412 U.S. 94, 116-21 (1973) (plurality opinion) (emphasizing the importance of broadcasters' editorial autonomy in rejecting political advertisers' First Amendment challenge to broadcaster's refusal to sell them advertising time). For further discussion of these cases, see supra notes 14-28, 57-62, 68-71 and accompanying text.

312 See, e.g., text accompanying notes 138-49.

313494 U.S. 872 (1990); see supra notes 225-39 and accompanying text. 
ing neutrality. ${ }^{314}$ The textual grounding of both free exercise and nonestablishment interests animates the Court's choice of deference over denial in the religion setting, and deference sends a bold, simple message of judicial neutrality. As in the expressive access setting, however, the Court's failure to resolve First Amendment collisions yields normatively biased consequences, undermining the interests of minority religious believers while eroding restraints against government favoritism toward religion generally.

The ubiquity of neutrality rhetoric in religious accommodation cases belies the conceptual difficulty of figuring out what neutrality means when a religious believer tells a court that only treating her differently from nonbelievers can vindicate her constitutional rights. In the series of mandatory accommodation cases that began with Sherbert $v$. Verner, ${ }^{315}$ the Court initially posited a strong reading of the Free Exercise Clause as a necessary element of government neutrality toward religion. ${ }^{316}$ Without mandatory accommodations, the Court reasoned in the Sherbert line of unemployment benefits cases ${ }^{317}$ and in Wisconsin $v$. Yoder, ${ }^{318}$ religious believers suffer a special burden because their constitutionally guaranteed right to worship puts them at odds with the law in a distinctive way. As the Court advanced its view of free exercise neutrality, it necessarily ignored the question of whether mandatory accommodations might raise establishment concerns and thus violate a different sense of neutrality. Over time, however, the Sherbert view of neutrality eroded to nothingness. In a range of decisions that rejected mandatory accommodation claims, ${ }^{319}$ the Court directly retreated from the view that neutrality required a proactive view of the Free Exercise Clause. In permissive accommodation cases the Court at most ignored the Free Exercise Clause; at worst, in the decisions that struck down permissive accommodations, the Court aggressively denied the salience of free exercise considerations. ${ }^{320}$ Taken together, the post-Sherbert accommodation cases trace a trajectory from a confident view that the Free Exercise Clause serves neutrality to a deep sense of skepticism whether constitutionally mandated legal exemptions can ever comport with a proper view of neutrality.

314 See Smith, 494 U.S. at 890.

315374 U.S. 398 (1963); see supra notes 139-50 and accompanying text.

316 See Sherbert, 374 U.S. at 402.

317 See supra notes 151-54 and accompanying text.

318406 U.S. 205 (1972); see supra notes 155-60 and accompanying text.

319 See supra notes $162-85$ and accompanying text.

320 See supra notes 208-21 and accompanying text. 
In a counterintuitive parallel, the Court's approach to the seemingly antithetical Establishment Clause dimension of the religious accommodation cases displays the same trajectory from assertiveness to skepticism. The decisions that struck down permissive accommodations under a strong reading of the Establishment Clause held out a strong nonestablishment principle as the helpmate of neutrality as confidently as the Sherbert line had assigned the same value to a strong free exercise principle. These decisions maintained that relieving certain religious believers of legal burdens that everyone else must bear flouts government's obligation to treat believers of all faiths, and perhaps even nonbelievers, the same. Mirroring the strong free exercise decisions' disdain for the Establishment Clause, the Court's assertions of a strong Establishment Clause constraint on permissive accommodations necessarily denied or disregarded the notion of a constitutionally salient free exercise interest. More commonly, however, the Court in religious accommodation cases came to view the Establishment Clause as an impediment rather than an aid to neutrality. The Court rejected Establishment Clause arguments when it upheld permissive accommodations in the name of neutrality in Walz $v$. Tax Commission $^{321}$ and Corporation of the Presiding Bishop of the Church of Jesus Christ of Latter-Day Saints $v$. Amos. ${ }^{322}$ Over a wide range of mandatory accommodation decisions, the Court treated the Establishment Clause as utterly irrelevant. The Sherbert line of successful mandatory accommodation cases flatly denied any salience of the Establishment Clause; more damningly, even as the Court in the 1980s found numerous reasons to reject mandatory accommodation claims, it steadfastly refused to find any role for the Establishment Clause. ${ }^{323}$ As with the Free Exercise Clause, the Court's quest for neutrality in religious accommodation cases left the Establishment Clause behind. ${ }^{324}$

321397 U.S. 664 (1970); see supra notes 187-96 and accompanying text.

322483 U.S. 327 (1987); see supra notes 197-206 and accompanying text.

323 See supra Part I.B.1.

324 The Court's progression on the Establishment Clause side of the religious accommodation cases does not follow the neat chronology found on the Free Exercise Clause side. The idea of neutrality, however, has played a prominent role in a much broader set of Establishment Clause cases than merely religious accommodation cases, and the Court over the past three decades has moved inexorably toward the view that greater allowance for government support of religion serves neutrality under the Establishment Clause. See, e.g., Zelman v. Simmons-Harris, 536 U.S. 639, 654 (2002) (upholding a publicly financed school voucher program under the principle of government neutrality toward religion). Read against that background, the Court's treatment of nonestablishment interests in the religious accommodation cases tracks its treatment of free exercise interests in moving from assertiveness to deference in the name of neutrality. 
In both their free exercise and nonestablishment dimensions, the Court's religious accommodation decisions before 1990 oscillated wildly in their understandings of what governmental neutrality toward religion required.325 In addition, the Court's frequent denial of either free exercise or nonestablishment interests ran aground on the plain language of the First Amendment. Responding to these problems, Smith abandoned all efforts to secure neutrality by asserting one First Amendment principle while denying the other, opting instead for total deference to legislative discretion in all but the most extreme accommodation scenarios. ${ }^{326}$ Smith told elected officials that the Religion Clauses placed few, if any, barriers in the way of handling appeals for accommodations in whatever way any political majority found desirable. ${ }^{327}$ This approach replaced the earlier decisions' tangled pathways toward an elusive ideal of governmental neutrality with a meta-narrative of judicial neutrality. ${ }^{328}$ Smith allows the Court to claim immunity both from the danger that particular claimants' free exercise appeals will lead it to give religious believers benefits that nonbelievers might also desire and deserve and from the danger that aggressive appeals to nonestablishment principles will cause it to undermine religious liberty by taking a cramped view of permissible accommodations. Smith guarantees neutral outcomes by making neutrality mean whatever elected officials decide it means.

Combining a Free Exercise Clause that does nothing to guarantee religious exemptions with an Establishment Clause that does almost nothing to prevent them has produced a legal regime that strongly favors the interests of politically powerful religious institutions. Since 1989, Congress alone has enacted more than 200 religious exemptions, covering topics as diverse as land use restrictions, employment discrimination, and tax liability, while federal agencies and state legislatures have enacted countless others. ${ }^{329}$ Smith thus has provided an enormous windfall for religious entities that own substantial property, engage in significant commercial activity, and face major tax liability-primarily large, institutional Christian churches. ${ }^{330}$ This

325 See supra Part I.B.1-2.

326 See supra notes $225-39$ and accompanying text.

327 Employment Div. v. Smith, 494 U.S. 872, 878-79 (1990).

328 See Smith, 494 U.S. at 890 (asserting that the political disadvantaging of minority religions under a discretionary accommodation regime "must be preferred to a system ... in which judges weigh the social importance of all laws against the centrality of all religious beliefs").

329 See Henriques, supra note 240.

330 See generally id. (providing examples of benefits churches experience with exemptions). 
state of affairs presents two constitutional problems. First, it reflects the political majority's propensity to privilege religious beliefs over functionally equivalent nonreligious commitments of conscience. ${ }^{331}$ Second, in Stephen Carter's apt summary, "what we are bold to call neutrality means in practice that big religions win and small religions lose."332 Marginal religious believers-splinter or fledgling churches, groups whose belief systems resist institutional organization, and idiosyncratic believers with no church affiliation-gain little or no benefit from the institutionally focused accommodations that have followed Smith. Religious outliers have found episodic success in compromising with the political majority to secure particular accommodations, ${ }^{333}$ and all believers can avail themselves of general statutory exemptions such as the Religious Freedom Restoration Act of 1993 (RFRA). ${ }^{334}$ Even general exemptions, however, primarily manifest the perspectives and influence of the Christian majority, ${ }^{335}$ and in general minority believers benefit only modestly from a majoritarian system that predictably favors the majority's interests. ${ }^{336}$ The Court prior to Smith

331 See generally Lisa Schultz Bressman, Accommodation and Equal Liberty, 42 WM. \& MARY L. Rev. 1007, 1015-24 (2001) (arguing that legislatures should adopt an "equal liberty approach," extending permissive accommodations to "similarly situated nonreligious claimants" because otherwise religious believers are given privilege over their nonreligious counterparts); Christopher L. Eisgruber \& Lawrence G. Sager, The Vulnerability of Conscience: The Constitutional Basis for Protecting Religious Conduct, $61 \mathrm{U}$. CHI. L. REv. 1245, 1291-97 (1994) (arguing for application of an "equal regard" principle to religious and secular claims of conscience).

332 Stephen L. Carter, Religious Freedom as if Religion Matters: A Tribute to Justice Brennan, 87 CAL.. L. Rev. 1059, 1063 (1999).

333 See Jesse H. Choper, Comments on Stephen Carter's Lecture, 87 CAL. L. Rev. 1087, 1089-90 (1999) (discussing instances of specific accommodations for minority religions).

33442 U.S.C. $\$ \S 2000 \mathrm{bb}$ to $2000 \mathrm{bb}-4(2000)$, invalidated in part by City of Boerne v. Flores, 521 U.S. 507 (1997). Dean Choper holds out the passage of RFRA as the strongest evidence of the Smith neutrality regime's benefits for minority religions. See Choper, supra note 333, at 1090. RFRA and its state equivalents, however, merely demonstrate formal legislative nondiscrimination against minority religions in a general scheme that primarily benefits Christian churches. Moreover, the fact that RFRA statutes operate through a judicial mechanism-requiring heightened scrutiny of accommodation claims-underscores legislators' inattention to religious believers' specific needs.

335 See Suzanna Sherry, Religion and the Public Square: Making Democracy Safe for Religious Minorities, 47 DePAUL L. REv, 499, 507-16 (1998) (discussing differences between Christianity and Judaism that make religious accommodation more salient to Christians).

336 See McConnell, supra note 234, at 1130-36 (criticizing the majoritarian bias of Smith); Kathleen M. Sullivan, Religion and Liberal Democracy, 59 U. CHI. L. Rev. 195, 216 (1992) (contending that Smith exchanges judicial recourse more useful to minori- 
certainly failed to resolve these problems of favoritism, but the mass of elected officials whom Smith empowered have made no effort to address them.

As in the expressive access context, the Court's deconstitutionalization of religious accommodation might conceivably reflect a considered normative judgment. Thoughtful commentators have argued that, on a proper understanding, the Establishment Clause does nothing more in the religious accommodation setting than buttress the Free Exercise Clause mandate that government stay out of religious believers' way. ${ }^{337}$ However, even if we accept that argument's normative orientation and look past its incompatibility with any notion of constitutional evolution, the Court has never embraced it. Indeed, the Smith Court provided no account at all of how and why the Establishment Clause does or does not impact accommodation cases. On the free exercise side, the Court has posited a substantive distinction between discrimination against religion and mere nonaccommodation. ${ }^{338}$ That distinction, however, works only from the perspective of the government. Legal burdens on free exercise fall just as heavily on the burdened believer whether they result from discriminatory animus or administrative convenience. Thus, the distinction requires a normative defense of the Court's choice of perspective, and all Smith offers is a broadly stated alarm about anarchy and a critique of past decisions' assertedly incurable practical failings. Once again, the Court treats a contestable doctrinal choice with strong normative consequences as if it emerged organically and neutrally from the Constitution.

\section{Neutrality in Religious Speech Cases}

The Court's account of neutrality in the religious speech cases hybridizes its understandings of how the two First Amendment interests that collide in those cases-expressive autonomy and the nonestablishment principle-operate in their respective native settings of expressive access and religious accommodation disputes. The expressive access cases declare that the Court considers expressive autonomy sufficiently central to free speech protection that the First Amend-

ties than to majorities for legislative recourse more accessible to majorities than to minorities).

337 See Laycock, supra note 289, at 1001-06 (arguing for substantive neutrality, under which the government must minimize both encouragement and discouragement of religion); McConnell, supra note 135, at 690 (characterizing both the Free Exercise Clause and the Establishment Clause as designed to protect religious freedom).

338 See supra notes 133-36 and accompanying text. 
ment has no room for any right of expressive access. ${ }^{339}$ The religious accommodation cases minimize the importance of establishment concerns, broadly licensing substantial government support for religious institutions. ${ }^{340}$ Given those positions, the Court in the religious speech cases inevitably portrays the primacy of religious speakers' expressive autonomy over the government's Establishment Clause concerns as definitive of neutral outcomes. As Justice Kennedy declared in Rosenberger,341 "the guarantee of neutrality is respected, not offended, when the government, following neutral criteria and evenhanded policies, extends benefits to recipients whose ideologies and viewpoints, including religious ones, are broad and diverse."342

The distinctive factual settings of the religious speech cases preclude the sort of broad conclusion I have reached in the expressive access and religious accommodation settings about the normative consequences of the Court's view of neutrality. Religious groups-all of them Christian-prevailed in each case, ${ }^{343}$ but those consistent outcomes might simply follow from the consistency of the cases' fact patterns. The Court's view of neutrality in the religious speech cases, however, reflects a decision against an alternative course of action. The Justices could have followed their approach from the expressive access setting by deferring to legislative discretion where the government decided to subordinate expressive autonomy to a competing First Amendment interest. ${ }^{344}$ That approach would have fit more comfortably in the religious speech cases, where the government invoked an interest with undeniable constitutional salience, than in the expressive access cases, where the Court deferred to the government's solicitude for an expressive access interest whose First Amendment pedigree the Court itself had flatly denied. ${ }^{345}$ That the religious speech cases nonetheless opt for denial over deference at least raises the possibility that here, as in the other First Amendment collision settings, the Court's projection of neutrality obscures a normative bias: in this context, a preference for enhancing religious speakers' prominence and influence in public discourse.

\footnotetext{
339 See supra notes 299-306 and accompanying text.

340 See supra notes 321-24 and accompanying text.

341515 U.S. 819 (1995); see supra note 268 and accompanying text.

342 See Rosenberger v. Rector \& Visitors of Univ. of Va., 515 U.S. 819, 839 (1995); supra note 273 and accompanying text.

343 See supra Part I.B.3.c.

344 See supra Part I.A.

345 See supra notes 307-11 and accompanying text.
} 
[VOL. 83:1

\section{The Troubling Allure of Neutrality}

The Court in First Amendment collision cases purports to apply neutral principles of decision, but the results it reaches consistently advance particular normative values. In expressive access cases, the Court's persistent denial of any First Amendment grounding for access interests depends on a rigid account of the public-private distinction and a single-minded focus on individual autonomy. The resulting jurisprudence safeguards the expressive prerogatives of wealthy and powerful speakers while disregarding the interests of underfunded and dissident speakers. ${ }^{346}$ In religious accommodation cases, the extreme deference of Smith throws aside both the free exercise interests of believers in religions unfamiliar or distasteful to the majority and the nonestablishment interests of anyone troubled by exempting religious believers from generally applicable legal obligations. The resulting state of affairs allows political majorities to favor and disfavor religious practices at will. ${ }^{347}$ In religious speech cases, the Court combines its extreme solicitude for expressive autonomy with its view that the Establishment Clause places little or no constraint on religious claims to public resources. The apparent consequence is a stronger platform for religious speakers in public debate. ${ }^{348}$

Whatever the subjective appeal or offense of the normative slants in the Court's decisions, they belie its commitment to deciding cases in a neutral manner. If the Justices want us to believe that a neutral jurisprudence always favors established speakers and majoritarian religious institutions, they must at least defend their analyses in a way that reconciles those consistent results with some account of neutrality. Not one of the First Amendment collision cases, however, offers any such defense. That deficit of theory betrays the ultimate problem at the heart of the Court's approach. Even if the aspiration toward neutrality generated results that did not correspond with any normative preference, it would still drag the First Amendment down a blind alley. Neutrality means nothing without a baseline, but the presence of any baseline countermands neutrality. ${ }^{349}$ Neutrality thus describes an essentially futile goal for resolving constitutional conflicts.

346 See supra notes $294-311$ and accompanying text.

347 See supra notes 312-38 and accompanying text.

348 See supra notes 339-45 and accompanying text.

349 See Cass R. Sunstein, Neutrality in Constitutional Law (with Special Reference to Pornography, Abortion, and Surrogacy), 92 Colum. L. Rev. 1, 5-13 (1992) (criticizing the prevailing idea of neutrality in constitutional law as dependent on prepolitical distributions of resources that reflect normative biases); Mark V. Tushnet, Following the 
The Court's fixation on neutrality in the face of First Amendment collisions appears rooted in an excessive concern with judicial restraint. ${ }^{350}$ That concern reflects our legal culture's ongoing obsession with the countermajoritarian difficulty-the supposed incongruity of unelected judges overriding elected officials' policy choices. ${ }^{351}$ By pursuing a neutral jurisprudence, the Court seeks to assuage the concern that its power to hold legislative policy judgments unconstitutional will usurp democratic authority. ${ }^{352}$ That concern does not usually deter the Court from vigorous enforcement of the First Amendment in straightforward cases of government censorship, discrimination against religion, or patronage of religion. ${ }^{353}$ Unlike those scenarios, however, First Amendment collisions pit constitutional interests against one another, denying the Court the rhetorical clarity of a constitutional trump. ${ }^{354}$ The Court responds to this difficulty by employing denial and deference to maintain a posture of restraint. Denial obviates the need to choose between constitutional

Rules Laid Down: A Critique of Interpretivism and Neutral Principles, 96 HARv. L. REv. 781, 804-24 (1983) (arguing that legal principles cannot be neutral because they necessarily reflect social practices).

350 The Seventh Circuit, in rejecting an unsuccessful patronage job seeker's challenge to a state party official's backing of a rival job candidate, has stated this concern explicitly:

[W] e do not believe . . . that it is for us to establish a hierarchy of First Amendment rights by granting one First Amendment remedy that denigrates another First Amendment right. The machinery of the courts may not be invoked to protect one First Amendment right at the expense of the other.

Tarpley v. Keistler, 188 F.3d 788, 796 n.7 (7th Cir. 1999).

351 See Barry Friedman, The History of the Countermajoritarian Difficulty, Part One: The Road to Judicial Supremacy, 73 N.Y.U. L. Rev. 333, 334 (1998) (calling the countermajoritarian difficulty "the central obsession of modern constitutional scholarship"). The classic articulation of the countermajoritarian difficulty is ALEXANDER M. BicKEL, The Least Dangerous Branch 16-23 (Yale Univ. Press 2d ed. 1986) (1962).

352 Justice Frankfurter, in explaining his vote to affirm convictions for teaching Communist doctrine, addressed this concern directly:

Free-speech cases are not an exception to the principle that we are not legislators, that direct policy-making is not our province. How best to reconcile competing interests is the business of legislatures, and the balance they strike is a judgment not to be displaced by ours, but to be respected unless outside the pale of fair judgment.

Dennis v. United States, 341 U.S. 494, 539-40 (1951) (Frankfurter, J., concurring).

353 See, e.g., Church of the Lukumi Babalu Aye, Inc. v. City of Hialeah, 508 U.S. 520, 524 (1992).

354 See generally Ronald Dworkin, Rights as Trumps, in Theories of Rights 153, 154 (Jeremy Waldron ed., 1984) (setting forth the equal concern theory of why certain rights should trump contrary political decisions). 
values by leaving only one constitutional value extant or salient to the case. Although the Court's determination that the First Amendment contains no right to expressive access manifests a highly subjective constitutional judgment, the rhetoric of denial allows the Court to present that judgment as a neutral insight that the right simply does not exist. Deference directly subordinates the Court's decisional authority to the elected branches' discretion, although the Court's decisions about when to defer may substantially channel the effects of that discretion. ${ }^{355}$

Even aside from any normative bias it might obscure, the problem with the Court's refusal to confront First Amendment collisions is that it marginalizes the First Amendment as a check on majoritarian caprice and a guarantor of robust democratic discourse. Concerns about judicial subjectivity should not preclude substantive judicial enforcement of the First Amendment. Neutrality should not crowd out democratic dynamism. To the extent that First Amendment collisions require the Court to make value judgments, it must root its judgments in broadly accepted values, articulate those values, and defend its judgments forthrightly. It must develop a basis for substantively adjudicating collisions of First Amendment interests that the people and the other branches and levels of government can embrace as democratically legitimate. ${ }^{356}$ It must ensure that its approach to First Amendment collisions keeps faith with democracy, both by respecting the proper authority of elected officials and by vigorously enforcing the First Amendment. The final section of this Article contends that the Court can meet this challenge by asking, as to each case of colliding First Amendment interests, one central question: which competing interest, if it prevails in the circumstances of the case, will go further toward advancing participation in the institutions and processes of democratic self-government?

355 See Louis Michael Seidman, Our Unsetrled Constitution 32 (2001) (positing that the decision to remand contestable constitutional questions to the political process is itself a contestable decision); Eugene V. Rostow, The Democratic Character of Judicial Review, 66 HARv. L. REv. 193, 213 (1952) (noting that the judicial refusal to decide a constitutional question amounts to upholding the constitutionality of challenged government action).

356 Although my formulation of participation-enhancing review addresses the Court's countermajoritarian concern about substantive resolution of First Amendment collisions, the people's demonstrated ability to affect the shape of constitutional judicial review over time should form part of the context for assessing that concern. See generally Barry Friedman, Mediated Popular Constitutionalism, 101 Mich. L. Rev. 2596, 2613-29 (2003) (discussing the capacity of public opinion to constrain judicial autonomy). 


\section{B. Participation-Enhancing Review as a Constitutional Basis for Resolving First Amendment Collisions}

This final section proposes a basis for substantive constitutional adjudication of cases that present colliding First Amendment interests. The starting point for my prescription is the theory of representation-reinforcing review, which anchors judicial review in the dictates of democracy in order to justify the sort of assertive constitutional judging that the Court in First Amendment collision cases has worked so hard to avoid. Limitations of classic representation-reinforcing review prevent it from supporting adjudication of First Amendment collisions. Those limitations fall away, however, if we modify the theory of representation reinforcement by taking a substantive rather than merely formal view of what meaningful participation in democratic processes entails. This substantive participation value gives constitutional priority to enhancing the informative and inclusive dimensions of democratic discourse, and it can thus animate judicial review of First Amendment collision cases. The result, participationenhancing review, gives courts a normative framework, grounded in widely shared democratic commitments, for resolving First Amendment collisions. By offering a proceduralist solution, I do not mean to embrace the view that countermajoritarian concerns should limit judicial review to process corrections. ${ }^{357}$ I simply propose a basis for substantively resolving First Amendment collisions that directly addresses the Court's reason for resorting to denial and deference.

\section{The Value and Limits of Representation-Reinforcing Review}

The foregoing discussion attributed the Court's futile pursuit of neutrality in adjudicating colliding First Amendment interests to our legal culture's discomfort with unelected judges' supposed encroachment on elected officials' policymaking authority. ${ }^{358}$ The most substantial theoretical effort to accommodate this countermajoritarian difficulty has been the theory of representation-reinforcing judicial review, articulated by Justice Stone in footnote four of United States $v$.

357 Three important insights challenge the premises of procedural theories of judicial review: that legislatures do not reflect the people's will to the extent procedural theories assume; that courts reflect the people's will to a greater extent than procedural theories assume; and that the judicial role in our system contributes to, rather than detracts from, our Constitution's conception of democracy. I incorporate these insights to defend judicial enforcement of expressive access rights in Magarian, supra note 5 , at $1406-29$.

358 See supra notes $346-55$ and accompanying text. 
Carolene Products Co. ${ }^{359}$ and crystallized most fully by John Hart Ely in Democracy and Distrust. ${ }^{360}$ The theory of representation reinforcement has two distinct elements. The first emerges from the Carolene Products suggestion that courts should not treat "legislation which restricts those political processes which can ordinarily be expected to bring about repeal of undesirable legislation" 361 as presumptively constitutional. That idea, in Ely's elaboration, justifies judicial review of certain breakdowns in the democratic process itself. ${ }^{362}$ The second element of representation reinforcement emerges from the Carolene Products suggestion that courts properly could invoke their constitutional authority to remedy "prejudice against discrete and insular minorities." 363 That idea, for Ely, justifies judicial review, primarily under the Fourteenth Amendment's Equal Protection Clause, of certain kinds of governmental attacks on minority groups' interests. ${ }^{364}$ The second, "minority protection" element of representation reinforcement arguably has been the theory's most practically important contribution to our law, and it has drawn the theory's heaviest criticism. ${ }^{365}$

The first element of representation-reinforcing review, the political process theory, provides a starting point for validating substantive adjudication of First Amendment collisions. The political process theory, as a justification for courts' overruling elected officials' policy choices, rests on the insight that our democratic system depends for its legitimacy on accurate representation. ${ }^{366}$ Where malfunctions in the political process produce elected branches of government that do not represent the people accurately, then the elected branches' authority is not truly democratic, and no basis exists for the concern that judicial review will override legitimate democratic policymaking. ${ }^{\mathbf{6 6 7}}$ Ely's elaboration of the political process theory derived

\footnotetext{
359304 U.S. 144, 152 n.4 (1938).

360 ELY, supra note 1, at 73-104.

361 Carolene Prods., 304 U.S. at 152 n.4.

362 See ELY, supra note 1, at 105-34.

363 Carolene Prods., 304 U.S. at 153 n.4.

364 See $\mathbf{E}_{\mathrm{LY}}$, supra note 1, at 135-79.

365 See Bruce A. Ackerman, Beyond Carolene Products, 98 Harv. L. Rev. 713, 717 (1985) (accepting the utility of the "political process" element of Carolene Products but strongly critiquing the "prejudice against discrete and insular minorities" formulation); Michael J. Klarman, The Puzzling Resistance to Political Process Theory, 77 VA. L. REV. 747, 784-88 (1991) (finding criticisms of Ely's "minority protection" argument convincing while defending Ely's "political process" argument).

366 See ELY, supra note 1, at 81-84.

367 See id. at 101-04 (advocating representation-reinforcing review as consistent with democracy).
} 
authority for judicial review from an ideal of democratic participation. ${ }^{368}$ He explained judicial remediation of procedural breakdowns as proper to ensure "the opportunity to participate . . . in the political processes by which values are appropriately identified and accommodated."369 Critics immediately objected that, contrary to Ely's proceduralist rhetoric, his explanation of judicial review as necessary to effectuate democratic participation necessarily entails a substantive value choice. ${ }^{370}$ Given the force of those criticisms, the most constructive way to understand Ely's foundational reliance on democratic participation is that democratic participation does encompass substantive values that are broadly accepted by the majority and/or ingrained in broadly shared constitutional understandings-values, in other words, that transcend the countermajoritarian difficulty. ${ }^{371}$

Ely's effort to withstand countermajoritarian objections came at the cost of advancing a somewhat impoverished notion of democratic participation, which I will call the formal participation value. For Ely, the need to protect democratic participation excused judicial interference with legislative prerogatives because participation generates effective representation. ${ }^{372}$ On the most basic level, participation for Ely meant electoral enfranchisement. ${ }^{373}$ Thus, Ely's political process theory defended the Warren Court's voting rights precedents on the basis that formal disenfranchisement prevented the excluded citizens from exercising political authority over their representatives. ${ }^{374}$ In addition, Ely recognized the importance of political speech as "critical to the functioning of an open and effective democratic process." 375 Thus, Ely defended the Warren Court's free speech precedents as aspects of his political process theory, on the basis that suppression of

368 See id. at $73-77$.

369 Id. at 77 . Ely also employed a different sense of democratic participation to explain the minority protection element of his theory. See id. (positing that judicial authority to protect minorities ensures "the opportunity to participate . . . in the accommodation [political] processes have reached").

370 See Laurence H. Tribe, The Puzzling Persistence of Process-Based Constitutional Theories, 89 YALE L.J. 1063, 1067-72 (1980) (contending that any commitment to democratic participation must draw upon substantive values to determine the details of what participation means); Mark Tushnet, Darkness on the Edge of Town: The Contributions of John Hart Ely to Constitutional Theory, 89 YALE L.J. 1037, 1045-48 (1980) (criticizing Ely's explanations of participation as a procedural justification for judicial review).

371 Ely himself anticipated this necessary elision. See ELY, supra note 1, at $75 \mathrm{n}$.*.

372 See id. at 105-25.

373 See id. at 117.

374 See id. at 116-25 (discussing judicial review of voting procedures).

375 Id. at 105. 
political speech prevented the putative speaker from exercising a different sort of political influence over her representatives. ${ }^{376}$ Ely's emphasis on representation, however, largely sublimates his account of participation. His theory simply aims to ensure that representatives can credibly claim to speak for all people constitutionally entitled to participate in their selection. As the critics of this proceduralist conception of participation charge, he never explains why, and to what extent, enhancing participation makes our democratic system better. ${ }^{377}$ Ely's resolution to avoid slippage into substantive values precludes any consideration of "better." His theory comprehends only "good enough"-good enough democratic participation to ensure accurate representation.

Ely's reliance on the formal participation value imposes important practical limits on his political process defense of judicial review. Those limits are visible from two different angles. First, in a formulation that continues to ground our understanding of representation reinforcement, Ely analogized his vision of appropriate constitutional judicial review to market correction under the antitrust laws. "[R]ather than dictate substantive results," he declared, courts should intervene "only when the 'market,' in our case the political market, is systematically malfunctioning." 378 Second, Ely tied the scope of the political process theory to intentional governmental meddling with the proper workings of democratic processes. His account of constitutional expressive freedom, for example, prescribes rigorous categorical review of regulations targeted at dangerous or unpopular messages but leaves regulations that incidentally limit speech subject only to a balancing analysis whose stringency largely depends on the danger of their covert intent to target messages. ${ }^{379}$ These two limitations ultimately collapse into one: courts properly may substitute their judgment about democratic processes for the judgment of the legislature only when a political majority has willfully leveraged its legal authority in order to suppress formal participation by a political minority"when ... the ins are choking off the channels of political change to ensure that they will stay in and the outs will stay out."380 Implicit in this approach is the corollary that only the political process itself can

376 See id. at 105-16 (discussing judicial review of speech regulations).

377 See Tribe, supra note 370, at 1070-72 (arguing that process-based theory requires a substantive account of political community and political interactions); Tushnet, supra note 370 , at $1047-48$ (criticizing political process theory for providing an insufficient account of the relationship between participation and democracy).

378 ELY, supra note 1, at 102-03.

379 See id. at 111-12.

$380 I d$. at 103. 
repair any asserted flaws in its own workings not traceable to deliberate abuses of governmental authority.

The formal participation value's limits prevent representationreinforcing review, as manifested in Ely's political process theory, from providing a way out of the Court's majoritarian aversion to resolving First Amendment collisions. First, Ely's approach necessarily precludes any account of what substantive values might guide adjudication of First Amendment collisions. His version of expressive freedom does not address the breadth and depth of political debate-the need for a system of free expression to bring the widest possible range of perspectives and participants into public discourse. ${ }^{381}$ About the Religion Clauses he says very little, only conceding that they embody substantive concerns ${ }^{382}$ and then mentioning religious freedom as an instance of minority protection. ${ }^{383}$ Second, few if any of the First Amendment collision cases involve the sort of willful governmental interference with democratic processes that justify Ely's "market corrections." Expressive access cases arise when a putative speaker complains that one, presumably unintended, consequence of the government's distribution of social benefits, such as broadcasting licenses and zoning variances, is that the recipient of those benefits has used the power they confer to exclude the putative speaker. Religious accommodation cases, by definition, involve applications to religious believers of neutral, generally applicable laws, or decisions to exempt believers from the force of such laws. Government in the religious speech cases withholds certain resources from religious speakers, but it does so based on the dictates of the Establishment Clause. None of these scenarios raises the sort of procedural concern on which Ely focused.

The failure of representation-reinforcing review to reach cases of colliding First Amendment interests appears to validate the Court's determination to avoid substantive resolution of First Amendment collisions, returning us to square one. However, a principle of decision is

381 Ely makes only one oblique reference to a problem of expressive access. In describing the proper balancing analysis for regulations that only incidentally suppress speech, he suggests that "a more serious threat should be required [to justify the regulation] when there is doubt that the speaker has other effective means of reaching the same audience." Id. at 111.

382 See id. at 94.

383 See id. at 100 (emphasizing the role of the Free Exercise Clause in protecting minority religious believers and comparing its function to that of the Equal Protection Clause). Ely's only other allusion to the Establishment Clause also appears in his discussion of minority protection. See id. at 141 (discussing Epperson v. Arkansas, 393 U.S. 97 (1968)). 
available that, like the formal participation value, embodies democratic commitments sufficiently basic to alleviate concerns about judicial excess, while improving on the formal participation value's sense of democratic participation. Articulating that principle requires consideration of why, beyond Ely's account, we value democratic participation, and how participation benefits from the various interests protected by the First Amendment.

2. The Substantive Participation Value and ParticipationEnhancing Review of First Amendment Collisions

The significance of First Amendment collisions for the health of our democratic system lies in how differences between the litigants' participatory opportunities can affect the vitality of democratic processes. Behind individuals' formal interest in participating in selecting their representatives stands a systemic interest in ensuring that people with a wide range of viewpoints and from a diverse set of social backgrounds participate in debate about matters of public concern. In contrast to Ely's formal participation value, I call this systemic interest the substantive participation value. Emphasis on the substance of democratic participation fosters a healthy democracy in two important ways. First, maximizing the range of viewpoints present in public debate ensures that collective decisions about important policy questions - including but not limited to the election of representatives-will benefit from as much of society's accumulated wisdom (and also its informative stupidity) as possible. This is the informational benefit of democratic participation. Second, maximizing the range of participants present in public debate-rich and poor, old and young, members of diverse racial, religious, and experiential communities-ensures that as many people as possible will recognize and manifest their stakes in the collective decisions of the political community. This is the inclusive benefit of democratic participation. Both the informational and inclusive aspects of the substantive participation value depend on diversity in democratic participation. These benefits therefore highlight the instrumental importance of expressive dissension and religious pluralism for a healthy democratic system.

Cases of colliding First Amendment interests, as discussed above, do not fit the template of representation-reinforcing review because they do not necessarily entail deliberate discrimination by political majorities against minorities. ${ }^{384}$ Outcomes in colliding First Amend-

384 See supra Part II.B.1. 
ment cases, however, can make important differences in the informational and inclusive character of democratic processes. Any claim for expressive access or religious accommodation seeks to alter the balance of public discourse-to increase the force or influence of one expressive or religious perspective at the expense of another. We cannot rely on elected officials to resolve these conflicting dynamics of participation any more than we can overlook the "market failures" that Ely emphasized elected officials impose on representation, because the substantive participation value, like the formal participation value, derives from bedrock constitutional requirements for our democratic system. ${ }^{385}$ Accordingly, cases in which First Amendment interests collide require courts to step back from Ely's focus on the integrity of democratic representation to assess a dispute's impact on the character of democratic discourse itself. ${ }^{386}$ Applying the substantive participation value to collisions of First Amendment interests compels courts to inquire which of the colliding interests in a given case better serves to advance our system's overall interest in optimizing the informational and inclusive benefits of democratic discourse. This inquiry defines participation-enhancing review.

Participation-enhancing review applies intuitively to expressive access cases. A familiar tradition in First Amendment theory, exemplified by the work of Alexander Meiklejohn, identifies a healthy democratic process as the primary aim of speech protection. ${ }^{387}$ Elsewhere, I have advocated a version of this approach, which I call the public rights theory of expressive freedom. ${ }^{388}$ Theorists in the public rights tradition, most pointedly Jerome Barron, ${ }^{389}$ have derived from this democracy-centered conception of free speech a commitment to expressive access rights, or at least ample allowance for legislative and

385 On a practical level, structural problems in our electoral system have frayed the lines of political accountability necessary to motivate the elected branches to advance the informational and inclusive benefits of democratic participation. See Magarian, supra note 5, at 1413-24.

386 In this sense, the substantive participation value offers a partial response to objections that Ely's account of democratic participation pays insufficient attention to the normative shape participation should take. See supra note 370 and accompanying text.

387 See generally MeiklejoHn, supra note 3, at 42 (arguing that freedom of speech "is the basic postulate of a society which is governed by the votes of its citizens").

388 See generally Magarian, supra note 48, at 1972-91 (contrasting the private rights theory and the public rights theory).

389 See generally BARRON, supra note 3, at 300-03 (analyzing the state of access rights to various forms of media and arguing that a right of access for minorities "is one way of grappling with both the enormous power of the mass media and the difficulty of mass participation in it"). 
regulatory access reforms. ${ }^{390}$ The Court in recent decades has almost completely abandoned the public rights theory in favor of an alternative I have labeled the private rights theory of expressive freedom, which safeguards against government interference the expressive autonomy of those who already possess the means to speak. ${ }^{391}$ The Court's wholesale denial in the expressive access setting of First Amendment access rights in favor of a single-minded commitment to expressive autonomy bespeaks the private rights theory's dominance. Participation-enhancing review, in contrast, would not entail any fundamental choice between the two theories. A judge in a given case could hold, within the boundaries of participation-enhancing review, that vindication of expressive autonomy best advanced the substantive participation value. ${ }^{392}$ Participation-enhancing review only precludes the Court's present position that expressive access cases present no occasion for substantive constitutional adjudication, either because no First Amendment interest beyond autonomy exists or because elected officials, not judges, should decide which distribution of expressive opportunities comports with the First Amendment. 393

We generally view the Religion Clauses as protecting substantive rather than procedural interests. ${ }^{394}$ Religious accommodation cases, however, represent a legal Waterloo for those substantive interests: the tension between free exercise interests in accommodation and nonestablishment concerns about accommodation has led the Court

390 On the divergence between proposals for expressive access rights and expressive access reforms, see Magarian, supra note 5, at 1376-88.

391 See Magarian, supra note 48 , at $1980-88$.

392 Indeed, no democracy-focused free speech theory denies that expressive autonomy plays an important role in advancing effective democratic government. See C. Edwin Baker, Media, Markets, and Democracy 129-53 (2002) (discussing the instrumental value of media autonomy under various democratically grounded conceptions of press freedom); Magarian, supra note 298, at 151-55 (discussing the role of autonomy in a public rights theory of expressive freedom); Robert C. Post, Racist Speech, Democracy, and the First Amendment, 32 WM. \& Mary L. Rev. 267, 284 (1991) (describing expressive freedom as necessary to reconcile individual autonomy with collective self-government).

393 Because expressive access cases typically involve putative speakers' claims of access rights to nominally private expressive property, substantive judicial resolution that takes access interests into account would require altering the normative terms of the public-private distinction. Elsewhere I have argued that the public-private distinction should shield the expressive autonomy of natural persons, while courts should assess the rights and obligations of nongovernmental institutions based on each institution's instrumental value for democratic discourse. See Magarian, supra note 298, at $146-72$.

394 See, e.g., Tribe, supra note 370, at 1065 (characterizing the Religion Clauses as “[p]lainly ... substantive"). 
almost completely to foreswear constitutional adjudication. ${ }^{395}$ The substantive participation value, while not the primary object of either Religion Clause, provides a path through the Court's reticence. The Free Exercise Clause and the Establishment Clause share a role in setting normatively desirable terms for democratic discourse. Religious identity and experience can go far toward shaping a person's or group's democratic participation. Government suppression of a given religious belief or practice, even if inadvertent, can marginalize religious believers by forcing them to choose between legal authority and their religious convictions, discouraging them from engaging with the political community. On the other hand, special government solicitude for a given religious belief or practice can elevate the status of the beneficiaries, thereby denigrating adherents of other faiths and nonbelievers. Justice O'Connor's notion that an improper state endorsement of religion "sends a message to nonadherents that they are outsiders, not full members of the political community, and an accompanying message to adherents that they are insiders, favored members of the political community" 396 goes some distance toward capturing this democratic dimension of religious status. ${ }^{397}$ The substantive participation value would incline courts to favor egalitarian accommodations necessary to prevent political marginalization of religious minorities ${ }^{398}$ and idiosyncratic accommodations with sufficiently narrow scope or subject matter to avoid or obviate the establishment danger of privileging religious status or belief. ${ }^{399}$ Conversely, courts under participation-enhancing review would disfavor accommodations that benefited politically powerful institutions or enhanced political power based on religion.

Participation-enhancing review necessarily discards representation-reinforcing review's requirement of intentional government

395 See supra Part I.B.3.

396 Lynch v. Donnelly, 465 U.S. 668, 688 (1984) (O'Connor, J., concurring).

397 Other efforts to understand the Religion Clauses in democratic terms include Abner S. Greene, The Political Balance of the Religion Clauses, 102 YALE L.J. 1611, 1614-40 (1993) (positing that the Establishment Clause excludes religious values from the political sphere while the Free Exercise Clause excludes political authority from the religious sphere); Sullivan, supra note 336, at 198 (contending that the Religion Clauses protect "religious liberty insofar as it is consistent with the establishment of the secular public moral order").

398 On the desirability and constitutional viability of egalitarian accommodations in the context of the federal Religious Freedom Restoration Act of 1993 (RFRA), 42 U.S.C. $\S \S 2000 \mathrm{bb}$ to $2000 \mathrm{bb}-4$ (2000), invalidated in part by City of Boerne v. Flores, 521 U.S. 507 (1997), see Magarian, supra note 136, at 1992-95.

399 On the desirability and constitutional viability of idiosyncratic accommodations, again in the context of RFRA, see Magarian, supra note 136, at 1995-97. 
interference with democratic processes, because First Amendment collisions rarely reveal the fingerprints of such deliberate abuse. ${ }^{400}$ While the logic of representation-reinforcing review does not compel the intent requirement, the requirement bolsters the formal participation value's constraint on judicial discretion. ${ }^{401}$ That additional measure of constraint, however, carries a steep cost. At the extreme, intent analysis can warp constitutional doctrine beyond recognition, as in its essential contribution to the Burger and Rehnquist Courts' position that the Equal Protection Clause primarily serves to prevent racial discrimination against white people. ${ }^{402}$ In the context of First Amendment collisions, the intent requirement abandons constitutional disputes to the vagaries of unstated or unconscious legislative motives, whose unintended consequences play out in the economic market. In the distribution of opportunities for democratic participation, neither legislative instinct nor market exchange produces random outcomes. A majority Christian legislature-the only kind found in this country-can favor Christian perspectives or disregard the perspectives of believers in minority faiths without the slightest ill intent. The economic market inherently privileges the perspectives of wealthier speakers, a salient bias for all manner of important policy debates. We should expect better than unintentionally biased outcomes in disputes that implicate such matters of core constitutional concern as expression and religion. The risk that judges, although limited by the substantive participation value, might nonetheless find openings for their subjective preferences is a fair price to pay for the guarantee that the branch charged with constitutional interpretation will enforce the First Amendment in democratically salient disputes about free speech and religious liberty.

Some will object to participation-enhancing review's directive that courts make certain qualitative assessments in the sensitive areas of speech and religion. Robert Post exemplifies this sort of objection in the distinctive context of decision rules for allocating government

400 See supra Part II.B.1.

401 See Klarman, supra note 365 , at 761 n.68 (acknowledging that political process theory can encompass racial and religious discrimination but opposing such an extension because "it would require courts to undertake inevitably speculative inquiries"). 402 See, e.g., Adarand Constructors, Inc. v. Pena, 515 U.S. 200, 227 (1995) (striking down a federal minority set-aside program as a violation of equal protection); Shaw v. Reno, 509 U.S. 630, 642 (1993) (finding that a challenge to an electoral district designed to remedy discrimination against African Americans stated an equal protection cause of action). Ely, although committed to the intent requirement, avoided the Court's fallacious fixation on "reverse discrimination" by determining that, under the representation reinforcement theory, the white majority cannot discriminate against itself. See ELY, supra note 1, at 170-72. 
subsidies, arguing that judicial evaluation of the relative marginalization of ideas in public debate would be impractical at best and impermissibly content-based at worst. ${ }^{403}$ Post is right to call attention to the practical challenges of evaluating social power differentials as part of constitutional adjudication and to warn against the danger of bias in making such evaluations. I believe he is wrong, however, to presume that courts can coherently, let alone fairly, resolve conflicts rooted in power differentials through a filter of neutrality that obscures those differentials. ${ }^{404}$ This Article has shown that the Court's denial of expressive access rights and deconstitutionalization of religious accommodation disputes has covertly yielded normatively biased outcomes. Participation-enhancing review would, at worst, compel forthright and transparent assessments of First Amendment collisions. In addition, I feel confident that more people would find the substantive participation value consistent with their understanding of courts as legitimate actors in our democratic system than the Court's normative bias toward the status quo. Even if we accept at face value the Court's professions of neutrality in its approach to First Amendment collisions, its queasiness about assessing expressive access disputes' and religious accommodation decisions' effects on democratic participation leaves those effects to legislative discretion and the market. Opponents of such judicial assessments offer no persuasive reason to prefer those forces to judges where important constitutional values hang in the balance.

Participation-enhancing review will raise a more general concern among originalists ${ }^{405}$ and judicial minimalists, ${ }^{406}$ two groups that strive against any allowance for subjectivity in constitutional adjudication. The substantive participation value undeniably carries greater normative content than Ely's formal participation value. ${ }^{407}$ It reaches

403 See Robert C. Post, Subsidized Speech, 106 Yale L.J. 151, 188-89 (1996).

404 Indeed, First Amendment doctrine focuses directly on power differentials when it takes special care to protect inexpensive means of expression. See Reno v. ACLU, 521 U.S. 844, 870 (1997) (emphasizing, in striking down an online "indecency" ban, that the Internet "provides relatively unlimited, low-cost capacity for communication of all kinds"); City of Ladue v. Gilleo, 512 U.S. 43, 57 (1994) (indicting a municipal ban on most residential signs as restricting "an unusually cheap and convenient form of communication").

405 See, e.g., BORK, supra note 293, at 143-60 (articulating and defending an originalist approach to constitutional interpretation).

406 See, e.g., Cass R. Sunstein, One Case at a Time 259-63 (1999) (arguing for the desirability of judicial minimalism on prudential and political grounds).

407 Others have suggested different ways in which Ely's procedural concerns might flower into justifications for more normatively robust varieties of judicial review. See Rebecca L. Brown, Liberty, the New Equality, 77 N.Y.U. L. REv. 1491, 1533 (2002) (advo- 
beyond the basic structural fact of democratic representation to advance a view about the broader character of democratic discourse. Even so, participation-enhancing review proceeds from understandings about our democratic system-and aspirations for it-that most members of our political community share. The formal participation value can underwrite judicial review whether one believes representatives should act as agents of their constituents' prepolitical interests or as trustees of their constituents' politically determined interests. ${ }^{408}$ The substantive participation value likewise can underwrite judicial review of First Amendment collisions under either of the most broadly recognized normative strands in our democratic fabric: liberal pluralism and civic republicanism. The pluralist ideal places great emphasis on the importance of effective political confrontations among different interest groups' material priorities. ${ }^{409}$ The substantive participation value can advance that ideal by helping to ensure that democratic processes accurately represent the variety and intensity of competing preferences. The republican ideal emphasizes the importance of deliberative discourse in pursuit of the common good.410 The substantive participation value can advance that ideal by helping to ensure that public deliberation encompasses every available viewpoint. Participation-enhancing review commits courts to show particular concern for dissident and minority perspectives, a commitment that comports in different ways with both the pluralist and republican ideals.

Participation-enhancing review, like representation-reinforcing review, does not dictate inevitable outcomes in particular cases. The salience of dissent and difference for the substantive participation value necessarily focuses judicial attention on the relative strength of litigants' opportunities for participation in democratic discourse. Inevitably and appropriately, however, different judges will take different views of what constitutes an underrepresented point of view or an unacceptable burden on a person's or group's ability to participate

cating judicial examination of public reasons for burdens on individual liberty as a species of representation-reinforcing review); William N. Eskridge, Jr., Pluralism and Distrust: How Courts Can Support Democracy by Lowering the Stakes of Politics, 114 YALE L.J. 1279, 1293-1317 (2005) (proposing an extension of representation-reinforcing review based on contemporary conditions of pluralist democracy).

408 See Hanna Pitkin, The Concept of Representation 127-31 (1967) (distinguishing agency and trusteeship models of representation).

409 See, e.g., Eskridge, supra note 407, at 1302-05 (suggesting that proper representation-reinforcing review in speech cases should protect the ability of opposing groups to associate for expressive purposes).

410 See generally Frank I. Michelman, Traces of Self-Govermment, 100 Harv. L. Rev. 4, 17-55 (1986) (discussing the civic republican tradition). 
meaningfully in democratic discourse. In some expressive access cases the autonomy interest will prevail, while in others the access interest will prevail. Courts will grant some religious accommodations under the Free Exercise Clause while denying others under the Establishment Clause. Courts in some cases will ratify regulatory efforts to resolve First Amendment collisions as consistent with the substantive participation value. All participation-enhancing review requires is for every court that confronts a collision of First Amendment interests to reach its result-and justify the result to the people-in terms of the court's own best sense of the substantive participation value. Brief reexamination of an emblematic case from each category of First Amendment collisions suggests how that assessment could work.

The substantive participation value acknowledges our self-governing society's powerful interest in opening public debate to the widest possible range of speakers and viewpoints, to inform the people about alternatives to the status quo and to give dissenters an active stake in the democratic process. In Hurley different understandings of that value could have caused either the parade organizers or the gay marchers to prevail under participation-enhancing review. ${ }^{411}$ Rather than denying the gay marchers' expressive access interest, the analysis would begin by recognizing that both sides presented serious First Amendment interests. The outcome would turn on which of those interests appeared less securely protected by the political status quo and, accordingly, which result would make democratic discourse more informative and inclusive. The court might have concluded that the parade organizers' exclusion of the gay marchers conveyed or preserved a message of traditional values, distinction between ethnic pride and identity politics, and/or opposition to substantive elements of the gay-lesbian political agenda unlikely to find comparable outlets elsewhere in public debate. On the other hand, the Court might have decided that the parade offered the gay marchers a unique and important platform from which to confront entrenched prejudice or disapproval.

Participation-enhancing review takes account of religious accommodations' value for ensuring religious believers' ability to participate fully in democratic processes and also of religious accommodations' danger for making religious faith a basis for undue enhancements in societal or political status. In Smith those considerations might have cut either way, but they necessarily would have precluded the actual Smith doctrine of radical deference. 412 The Native Americans who

411 See supra notes $37-47$ and accompanying text.

412 See supra notes 225-39 and accompanying text. 
sought relief in Smith from the effects of Oregon's drug laws on their sacramental use of peyote undeniably represented a community on the political and religious margins. Accordingly, participationenhancing review would have offered a strong basis for concluding that they needed the requested accommodation in order to maximize their engagement with the political community at large, while their minority status and highly idiosyncratic request diminished any risk of establishment from the accommodation. Conversely, the Court might have rejected the accommodation claim, either because the choice to which Oregon's law put the Native Americans did not seriously undermine their capacity for full participation in democratic discourse or because the accommodation would have deviated so powerfully from generally applicable law that, notwithstanding the beneficiaries' minority status and the accommodation's idiosyncratic character, granting it would have sent a chilling message to nonbelievers about the political importance of religion. ${ }^{413}$

The religious speech cases juxtapose the substantive participation value's imperative to protect dissent against its imperative to promote religious inclusion while avoiding undue elevation of religion. Given those considerations, participation-enhancing review would have focused the Court in Rosenberger $v$. Rector $\mathcal{E}^{2}$ Visitors of University of Virginia $^{414}$ on the complex interaction between the dynamics of robust public discourse and the political salience of religious belief. The University in Rosenberger denied a Christian student group an otherwise generally available subsidy for student publications. ${ }^{415}$ The Court's determination whether that exclusion undermined the substantive participation value would have turned on at least three axes. First, the Court would have needed to fix the relevant frame of reference for assessing the University policy's impact. Christian perspectives-the subjects of all the religious speech cases ${ }^{416}$ - exert considerable influence in the United States generally, and probably greater influence in Virginia. On the other hand, Christian perspectives might well be in short supply at a large state university. Second, the Court would have needed to consider whether the University's

413 Participation-enhancing review would allow courts to reject religious accommodation claims based on government interests unrelated to the Establishment Clause. In sharp contrast to the Court's reflexive deference under Smith, however, attention to the substantive participation value would require courts to measure asserted government interests against a substantial conception of free exercise, in the manner of heightened constitutional scrutiny.

414515 U.S. 819 (1995); see supra note 268 and accompanying text.

415 See id. at 823-27.

416 See supra Part I.B.3.c. 
freedom to effectuate a distinctive educational mission contributed more to democratic discourse, at least in the circumstances of this case, than the Christian group's ability to bring its faith to bear on public debate. Finally, whereas the actual Rosenberger majority shrugged off the nonestablishment justification for the University's policy, ${ }^{417}$ participation-enhancing review would have required the Court to assess carefully the shape and severity of the establishment concern. Did the University's policy simply disadvantage the Christian group relative to comparable organizations, or did it preserve a key barrier between the governmental and religious spheres?

The foregoing examples demonstrate that the inquiries that the substantive participation value mandates - the particular standards for participation in a healthy democracy, the relative degree of different ideas' or speakers' representation in public debate, a given religious accommodation's likely costs and benefits for democratic participation-elude easy resolution and invite some measure of subjective analysis. The substantive participation value, however, carries sufficiently clear meaning to foreclose most normatively divisive judicial freelancing, and it embodies ideas about democracy that our society broadly accepts. Participation-enhancing review serves democratic values in the same manner as representation-reinforcing review, equipping courts with a substantive understanding of democracy and charging them with ensuring that resolutions of democratically salient legal disputes reflect that understanding.

\section{Conclusion}

This Article calls on courts to do something that disturbs many people: apply a necessarily broad normative framework to an important class of constitutional disputes. Participation-enhancing review of colliding First Amendment interests would require judges to consider whether ruling in favor of this putative speaker without means or that owner of expressive property, this legally burdened religious practitioner or that wary nonbeliever, would do more to advance our society's common interest in fostering informative, inclusive democratic participation. The theory allows for vindication of constitutional rights where the government has not discriminated intentionally, and the legal inquiry requires subjective judgment and leaves space for divergent outcomes. Skeptics, however, should consider the present alternative. The Supreme Court has demonstrated, relentlessly, how First Amendment collisions play out absent participation-enhancing review. Confronted with tension between two constitutional interests,

417 Rosenberger, 515 U.S. at $842-46$. 
the Court denies that one of the interests exists or matters. When government regulation-or, in the case of the Religion Clauses, the constitutional text-renders denial untenable, the Court defers evaluation of the constitutional interests at stake to the elected branches. These techniques of denial and deference aim to avoid excessive interference with elected officials' policymaking discretion.

In our system, however, the First Amendment supersedes elected officials' policymaking discretion. If the Court's duty to interpret the Constitution and impose its interpretation on disputes that implicate constitutional values extends even to cases in which First Amendment interests collide, then we need a theoretical basis for substantive judicial resolution of such cases. The theory this Article advocates, participation-enhancing review, proceeds from the same logic that fortifies the familiar countermajoritarian salve of representation-reinforcing review: it finds a basis for judicial action in our society's deeply ingrained understandings about the requirements of participatory democracy. Where representation-reinforcing review defends judicial redress of governmental affronts to the political process based on a formal participation value, participation-enhancing review extends that defense to First Amendment collisions based on a substantive participation value. The substantive participation value embodies our self-governing society's interest in informative, inclusive democratic participation. It accordingly calls particular judicial attention to the importance of dissent and difference for democratic discourse.

The present Court shows no inclination to reconsider its unduly restrained approach to First Amendment collisions. My hope is that participation-enhancing review's firm roots in our society's widely shared commitment to democratic participation will make the theory appealing in the future. The Constitution embodies our deepest democratic commitments, and the First Amendment's protections of speech and religion stand among the most crucial of those commitments. When legal disputes implicate expressive or religious interests, even if those interests clash, the Court should not elevate judicial restraint over substantive analysis through a futile pursuit of neutral decisional principles. Instead, it should assertively construe and apply the Constitution's commands. Participation-enhancing review would not fully obviate the majoritarian anxiety that judges, charged with implementing broadly conceived normative principles, might at times place their own subjective values above the will of the people's representatives. What participation-enhancing review would guarantee is that the democratic values manifest in the First Amendment would control the outcomes of the important legal disputes in which First Amendment interests collide. 